MirosŁaw WóJTOWicz

Uniwersytet Pedagogiczny, Kraków, Polska

\title{
Ksztaltowanie przemysłu samochodowego Argentyny w dobie globalizacji
}

\section{The Development of the Argentine Automobile Industry in the Age of Globalization}

\begin{abstract}
Streszczenie: Celem artykułu jest określenie przemian potencjału produkcyjnego argentyńskiego przemysłu samochodowego w latach 1952-2011. Zbadano także ewolucję strategii produkcyjnych i inwestycyjnych międzynarodowych koncernów motoryzacyjnych obecnych w Argentynie, uwarunkowaną zmianami koncepcji polityki gospodarczej, postępującą globalizacją produkcji oraz integracją w obrębie Mercosur. Początki tego przemysłu w Argentynie wiążą się z przyspieszoną industrializacją i modernizacją w okresie rządów Juana Perona. Rozwijany pod „osłoną” wysokich stawek celnych przemysł samochodowy miał się przyczynić do unowocześnienia i przekształcenia struktury gospodarczej kraju. W badanym okresie wyróżniono trzy fazy jego rozwoju. Pierwsza z nich (1952-1975) wiąże się z wprowadzeniem przemysłu samochodowego do Argentyny, które początkowo dokonało się przy dużym zaangażowaniu kapitałowym państwa oraz prywatnych przedsiębiorców argentyńskich. W drugim etapie, charakteryzującym się konsolidacją działających w kraju zakładów, decydującą rolę odegrały koncerny międzynarodowe. Druga faza (1976-1990) charakteryzuje się głębokim kryzysem tego sektora, na który złożyła się niekorzystna sytuacja gospodarcza kraju oraz błędnie prowadzona polityka przemysłowa, zbytnio liberalizująca import gotowych pojazdów. Doprowadziła ona nie tylko do spadku ilości produkowanych pojazdów, ale także do opuszczenia kraju przez kilka koncernów międzynarodowych. Ostatnia faza (1991-2011) cechuje się ponownym dynamicznym wzrostem produkcji, która w 2011 r. osiągnęła największą w historii wielkość. Sukces ten wynikał głównie z umiejętnie prowadzonej polityki w tym sektorze, w której nacisk położono na rozwój eksportu, wykorzystując powiększenie się rynku o państwa Mercosur.
\end{abstract}

Abstract: The aim of this paper is to determine the transformation of the production potential of the Argentine automotive industry in the years 1952-2011. The evolution of production and investment strategies of the international automotive companies were also examined, considering changes in the industrial policy, progressing globalization and integration within Mercosur. The origins of this industry in Argentina were associated with acceleration of industrialization and modernization under the rule of Juan Peron administration. Developed behind the "cover" of high tariffs, the automobile industry has contributed to the modernization and transformation of the economic structure of the country. The studied period can be divided into three main phases of development. The first phase (1952-1975) 
is associated with the introduction of the automobile industry to Argentina, which initially took place under the heavy involvement of the state and private capitals. Its second stage was characterized by the consolidation of the companies operating in the country with the decisive role played by transnational corporations. The second phase (1976-1990) covers the years of deep crisis in this sector, which was the outcome of the unfavorable economic situation in the country and wrong industrial policy liberalizing imports of finished vehicles. This led not only to the decrease in the number of produced vehicles, but also some of the automobile companies opted to leave the country. During the third phase (1991-2011) the auto sector witnessed a rapid increase in production, which reached the highest point in the history in 2011. This success was attained due to export-oriented policy in this sector, which took advantage of the creation of Mercosur.

Słowa kluczowe: Argentyna, przemysł samochodowy, Mercosur, industrializacja poprzez substytucję importu

Key words: Argentina, automobile industry, Mercosur, import substitution industrialization

\section{WsTĘP}

Początki przemysłu samochodowego w Argentynie sięgają pierwszej połowy lat 50 . XX w., co było związane z prowadzoną przez państwo polityką industrializacji poprzez substytucję importu. Rodzima produkcja miała za zadanie zastąpić trwający od końca I wojny światowej import samochodów, a następnie części do ich montażu. Rozwój krajowego przemysłu motoryzacyjnego był z jednej strony koniecznością, wynikającą z rosnących kosztów importowanych samochodów, których nie był w stanie zrównoważyć eksport tradycyjnych towarów, a z drugiej chęci i aspiracji dogonienia państw wysokorozwiniętych. Ówcześni politycy i ekonomiści zdawali sobie sprawę z roli tego sektora przemysłu w kreowaniu nie tylko postępu technicznego, ale także dużej liczby miejsc pracy, zarówno bezpośrednio przy produkcji pojazdów, jak i w zakładach kooperujących oraz dostarczaniu bardzo ważnych dla gospodarki (ale też i społeczeństwa) produktów, jakimi były samochody.

W blisko 60-letniej historii rozwoju sektora motoryzacyjnego w Argentynie dokonały się znaczące zmiany nawiązujące do jego światowych przekształceń, wynikających z postępujących procesów globalizacji, a także regionalnej integracji. Prześledzenie tego procesu oraz określenie przemian potencjału produkcyjnego argentyńskiego przemysłu samochodowego jest głównym celem poniższego opracowania. Ponadto, zbadano także ewolucję strategii produkcyjnych i inwestycyjnych międzynarodowych koncernów motoryzacyjnych inwestujących w Argentynie, uwarunkowaną zmianami koncepcji polityki gospodarczej, postępującą globalizacją produkcji oraz integracją w obrębie Mercosur.

\section{PierwsZy ETAP ROZWOJU MOtORYZACJI W Argentynie}

Początków przemysłu samochodowego w Argentynie należy doszukiwać się już w pierwszej połowie XX w. Kraj charakteryzował się wówczas stabilnością monetarną 
i sporymi zyskami z eksportu, co sprawiało, że uznawano go za najważniejszy rynek zbytu dla przemysłu motoryzacyjnego w Ameryce Łacińskiej. Znajduje to potwierdzenie w szybkim pojawieniu się na tym rynku największych koncernów samochodowych ze Stanów Zjednoczonych. W 1913 r. swoje biura handlowe otworzył Ford. Była to jego pierwsza filia w Ameryce Łacińskiej i zarazem druga poza granicami USA. W 1922 r. uruchomił on montownię sprowadzanych z zagranicy samochodów, co było zarazem sygnałem dla jego konkurentów, że rynek argentyński wart jest zainteresowania. W 1924 r. swoje przedstawicielstwo w Argentynie otworzył General Motors, a dwa lata później wybudował fabrykę na południe od Buenos Aires, która zajmowała się montażem samochodów z dostarczanych z zagranicy części. Ostatnim z koncernów, który zdecydował się wejść na rynek argentyński, był Chrysler, przy czym zgodził się on, aby reprezentowała go firma Fevre y Basset, która otworzyła montownię jego samochodów w San Justo (Belini 2006: 110; Jenkins 1987: 18-20).

Argentyna była stosunkowo chłonnym rynkiem zbytu na nowe samochody. W latach 1920-1930 liczba zarejestrowanych pojazdów wzrosła z 48 tys. do 435 tys. sztuk, zaś wskaźnik liczby mieszkańców przypadających na jeden samochód spadł z 204 do 35 (ryc. 1). Warto podkreślić, iż po początkowym żywiołowym wzroście parku samochodowego, ponownie tak niską wartość wskaźnik motoryzacji osiągnął dopiero w 1962 r. (Belini 2006: 111; Kosacoff i in. 1991: 6).

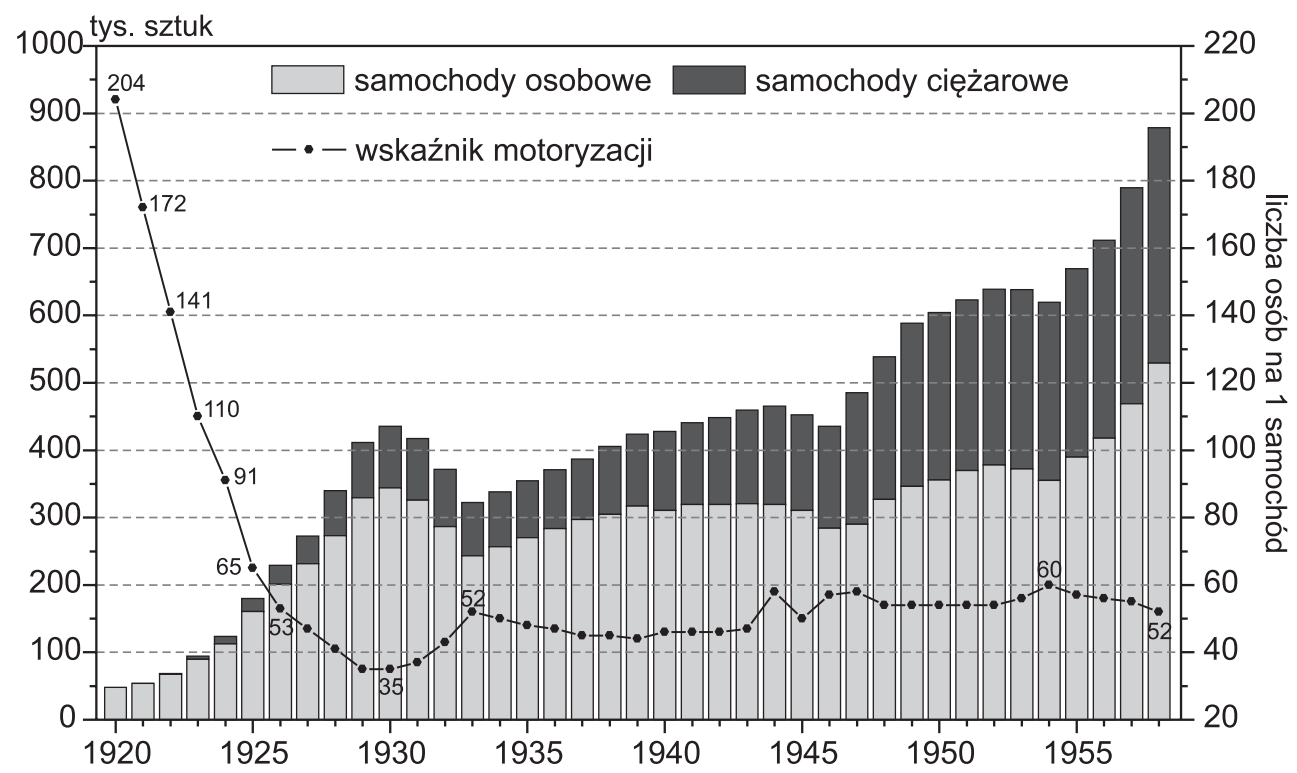

Ryc. 1. Zmiany wielkości parku samochodowego i wskaźnika motoryzacji w Argentynie w latach 1920-1958

Źródło: opracowanie własne na podstawie Belini 2006: 134

Początek lat 30. XX wieku wyznacza koniec pierwszej fazy rozwoju przemysłu samochodowego, która opierała się w całości na imporcie gotowych pojazdów lub wymagających 
jedynie montażu w systemie częściowego lub całkowitego rozłożenia na elementy składowe (semi-knocked-down - SKD lub completely-knocked-down-CKD). Polityka celna państwa, nakładająca znacznie niższe stawki na elementy do montażu (o 30\% niższe na CKD i o 15\% na SKD) była pierwszą próbą zachęcenia międzynarodowych koncernów samochodowych do rozwijania miejscowej produkcji. W pierwszym okresie, w strategiach rozwojowych głównych koncernów inwestujących w Argentynie, obecność na miejscowym rynku firm dostarczających podzespoły nie była konieczna, co sprawiło, że ich główni kooperanci nie byli zainteresowani otwieraniem produkcji. Stworzyło to lukę dla powstania rodzimych firm produkujących części zamienne na potrzeby szybko rosnącego parku samochodowego. Sektor ten rozwijał się szczególnie szybko w latach 30. XX. w. oraz w czasie wojny, kiedy to dostawy „oryginalnych” części ze Stanów Zjednoczonych bądź Europy zostały niemal całkowicie wstrzymane. Jedyną grupą kooperantów koncernów motoryzacyjnych, która pojawiła się w Argentynie już w tym pierwszym okresie, były firmy produkujące opony. W $1931 \mathrm{r}$. produkcję rozpoczęły zakłady koncernów Firestone i Goodyear (Jenkins 1987: 19-20; Schvarzer 1996: 6-7; Barbero i in. 2007: 194).

W latach 1920-1929 sprowadzono do Argentyny aż 469902 samochody, głównie takich firm, jak: Ford, GM, Fiat, które miały tu swoje montownie oraz Dodge i Chrysler, które działały poprzez swoich przedstawicieli (Barbero i in. 2007: 193). Żywiołowy rozwój importu samochodów do Argentyny w latach 20. XX wieku został przerwany przez kryzys światowy. W najbardziej kryzysowym 1932 roku sprowadzono jedynie 5331 pojazdów, a w całej dekadzie lat 1930-39 - 261,6 tys. sztuk. W wyniku spadającego importu samochodów i braku produkcji krajowej, park samochodowy Argentyny w latach 1930-1940 zmniejszył się o 1,8\%, z 435,8 do 427,8 tys. sztuk (Belini 2006: 113).

Kolejnym niekorzystnym okresem dla importu były lata II wojny światowej, kiedy to zaangażowanie w konflikt państw europejskich oraz Stanów Zjednoczonych spowodowało zahamowanie importu. W najgorszym 1944 roku sprowadzono jedynie 101 pojazdów, a w całym okresie 1939-1946 zaledwie 97,25 tys. sztuk (ryc. 2). Skumulowany w okresie wojennym popyt na samochody został zaspokojony masowym importem (głównie ze Stanów Zjednoczonych i Wielkiej Brytanii), który w 1948 r. przekroczył 80 tys. sztuk. Było to jednak krótkotrwałe ożywienie. Już w 1949 roku wyczerpały się rezerwy dewiz, a rząd nałożył restrykcje ograniczające import pojazdów, starając się w ten sposób ratować bilans płatniczy kraju (Jenkins 1987: 21; Belini 2006: 114; Barbero i in. 2007: 195).

Warto również zaznaczyć, iż spadek importu samochodów - obserwowany w latach 30. i 40. XX wieku - był wywołany nie tylko czynnikami zewnętrznymi, związanymi z mniejszą podażą samochodów w objętych kryzysem, a potem działaniami wojennymi USA i Europie. Bardzo ważny okazał się także spadek popytu w Argentynie, będący efektem światowego kryzysu gospodarczego. Doprowadził on bowiem do drastycznego spadku wartości argentyńskiego eksportu, co w konsekwencji ograniczyło środki, jakie można było przeznaczyć na zakup towarów za granicą i wymusiło na rządzie nałożenie ograniczeń importowych, w celu poprawienia bilansu płatniczego kraju. Po II wojnie światowej większość państw Ameryki Łacińskiej stanęła w obliczu pogarszania się relacji terms of trade, wynikającej ze specyfiki swoich gospodarek nastawionych głównie na eksport wstępnie przerobionych surowców 
mineralnych bądź produktów rolnych, których ceny na rynkach światowych malały, podczas gdy importowane wyroby przemysłu przetwórczego - szczególnie wysoko przetworzone i zaawansowane technologicznie - gwałtownie rosły. Państwa, które znalazły się w tej sytuacji, musiały krótkofalowo ograniczać wartość importu, aby zrównoważyć bilans handlowy, a długofalowo zmienić strategię rozwoju gospodarczego. W odpowiedzi na te wyzwania, w połowie lat 50. XX w. w dużych państwach Ameryki Łacińskiej upowszechniła się strategia rozwoju poprzez substytucję importu, zaproponowana przez argentyńskiego ekonomistę Raula Prebischa (Gocłowska-Bolek 2007). Sektor motoryzacyjny wydawał się szczególnie odpowiednim do zastosowania jej reguł, przy zaangażowaniu kapitałów, technologii oraz wiedzy koncernów międzynarodowych. Stąd w połowie lat 50. XX. w. Argentyna oraz inne duże państwa regionu (Brazylia, Meksyk) rozpoczynają drugi etap rozwoju przemysłu samochodowego, polegający na uruchomieniu miejscowej produkcji (Jenkins 1987: 55-64; Barbero i in. 2007: 194).

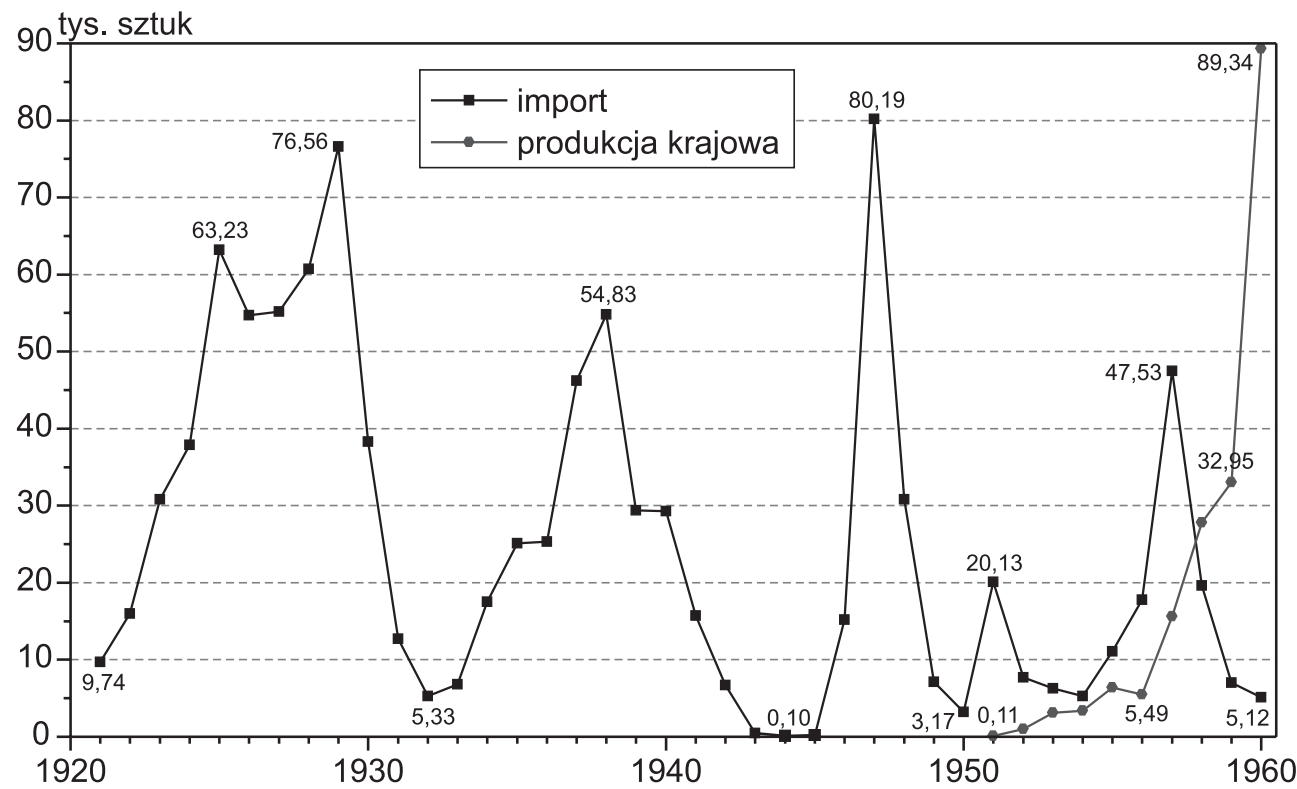

Ryc. 2. Zmiany wielkości importu i produkcji samochodów w Argentynie w latach 1921-1960 Źródło: opracowanie własne na podstawie danych z Barbero i in. 2007: 224-226

Drugi etaP ROZWoJU MotoryZaCJI w ArgENTYNIE

\section{Faza I - powstanie i konsolidacja przemysłu samochodowego 1952-1975}

Dekada lat 50. XX w. rozpoczyna drugi okres rozwoju, mający na celu stworzenie krajowego przemysłu samochodowego, w oparciu o kapitały argentyńskie oraz zagranicznych 
koncernów samochodowych. Okres ten można podzielić na trzy główne fazy, w obrębie których można dodatkowo wyróżnić kilka krótszych etapów. Pierwszą z nich, obejmującą lata 1952-1975, można nazwać fazą utworzenia i konsolidacji argentyńskiego przemysłu samochodowego. Składała się ona z dwóch etapów. Pierwszy, obejmujący lata 1952-1963, to etap tworzenia i „ukorzeniania” lokalnego przemysłu samochodowego, zaś drugi - obejmujący lata 1964-1975 - etap jego konsolidacji (Catalano Novick 1998: 30). W całym tym okresie w polityce państwa dominowała strategia rozwoju tego przemysłu poprzez substytucję importu (Jenkins 1987; Catalano Novick 1998; Catalan 2010).

Pierwszą próbę rozwinięcia rodzimej produkcji samochodów przedstawił prezydentowi Juanowi Peronowi w 1951 r. minister lotnictwa Juan San Martin, wykorzystując do tego celu zaplecze techniczne i siłę roboczą państwowych zakładów IAME (Industrias Aeronáuticas y Mecánicas del Estado) w Cordobie ${ }^{1}$. W listopadzie 1951 r. prezydent przychylił się do planów stworzenia w ramach IAME fabryki samochodów, a także wydał dekrety zapewniające środki w wysokości $60 \mathrm{mln}$ pesos na zakup licencji oraz koszty związane z uruchomieniem produkcji. W 1952 r. rozpoczęto produkcję pierwszych pojazdów modelu pick-up - Rastrojero, a rok później samochodu osobowego Justicialista² (Belini 2006: 117-119, Barbero i in. 2007: 197-198).

Drugim ważnym producentem samochodów, który zainteresował się rynkiem argentyńskim, był amerykański przedsiębiorca Henry Kaiser, który wśród swych licznych przedsiębiorstw był również właścicielem firmy Kaiser-Frazer Automobile Co., zajmującej się produkcją samochodów w Stanach Zjednoczonych i przeżywającej coraz większe problemy na tym rynku, spowodowane rosnącą konkurencją ze strony tzw. ,,wielkiej trójki”. W 1954 r. Henry Kaiser zaproponował Juanowi Peronowi uruchomienia fabryki samochodów w Argentynie, przy współpracy i pomocy finansowej władz. Po negocjacjach, 4 października 1954 r. udało się podpisać wstępne porozumienie między firmą Kaiser, IAME i rządem argentyńskim. Umowa zakładała powołanie nowego przedsiębiorstwa IKA (Industrias Kaiser Argentina S.A.), w którym 38\% akcji przypadało firmie Kaiser, 22\% - IAME a pozostałe 40\% zakupili drobni akcjonariusze argentyńscy. Po zgromadzeniu odpowiednich środków firma rozpoczęła budowę fabryki w Santa Izabel, w aglomeracji Cordoby. Rozwój firmy i uruchomienie produkcji zostało przerwane przez wojskowy zamach stanu, który w 1955 r. obalił rząd Juana Perona. Jednak zapewnienia nowych władz, iż będą respektować

${ }^{1}$ Państwowe zakłady IAME - Industrias Aeronáuticas y Mecánicas del Estado w Cordobie zostały utworzone w 1927 r. jako Fábrica Militar de Aviones (FMA) - strategiczna fabryka wojskowa, położona w centralnej części kraju z dala od granic (szczególnie granicy z Brazylią). Zajmowała się głównie produkcją samolotów, a z czasem także samochodów, traktorów, motocykli i różnych typów silników. W 1952 r. zatrudniała 8600 robotników i techników. W 1956 r., ze względu na zbyt duży rozrost przedsiębiorstwa - które z czasem rozwinęło się w konglomerat wielu zakładów specjalizujących się w różnych wyrobach - doszło do jego podziału. Część specjalizującą się w produkcji lotniczej przemianowano na DINFIA (Dirección Nacional de Fabricaciones e Investigaciones Aeronáuticas), natomiast z zakładów przeznaczonych do produkcji samochodów utworzono IME (Industrias Mecánicos del Estado) (Belini 2006: 117-118; Barbero i in. 2007: 197).

2 Nazwa modelu Justicialista nawiązuje do założonej w 1947 r. przez rządzącego wówczas Argentyną Juana Domingo Perona Partii Justycjalistycznej (Partido Justicialista). Miała ona symbolizować sukcesy gospodarcze realizowanej przez rząd polityki wspierania rozwoju rodzimego przemysłu. Po wojskowym zamachu stanu w 1955 r. zakazano używania jego pierwotnej nazwy, kojarzącej się z obaloną partią Juana Perona. W latach 1953-55 wyprodukowano jedynie 2300 sztuk pod nazwą Justicialista (Belini 2006: 118-119). 
zawarte wcześniej umowy pozwoliły ukończyć inwestycję i rok później rozpocząć produkcję (MacDonald 1988; Belini 2006). W latach 1956-1958 produkcja wzrosła z 2690 do 16902 pojazdów. Natomiast w 1959 r. IKA podpisała kontrakt z Renault, umożliwiający jej produkcję samochodów osobowych na francuskiej licencji. Dzięki temu wyraźnie wzrosła ogólna wielkość produkcji tej firmy. W najlepszym 1965 r. przekroczyła ona 55 tys. sztuk, co stanowiło 28\% ogólnej produkcji samochodów w Argentynie (ryc. 3).

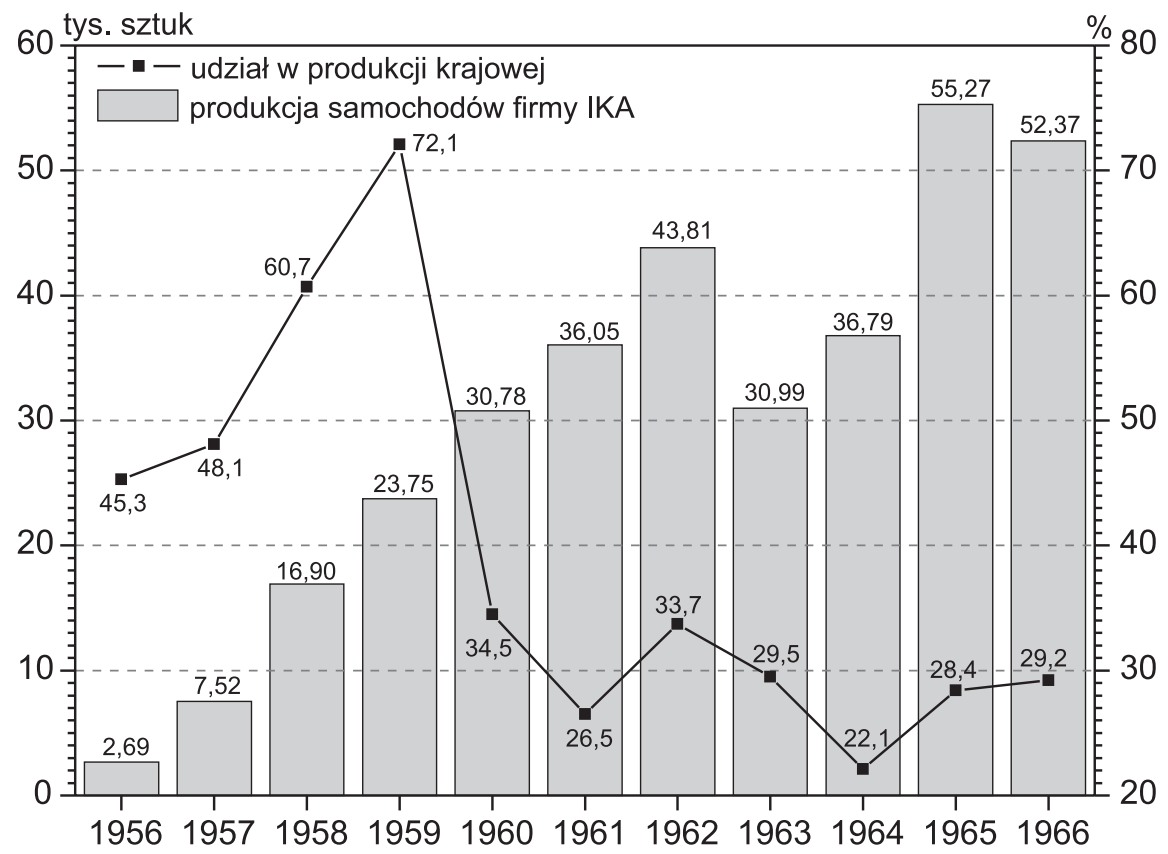

Ryc. 3. Zmiany wielkości produkcji oraz udziału samochodów wytwarzanych przez IKA w latach 1956-1966

Źródło: opracowanie własne na podstawie danych: Belini 2006: 128 (tab. 6) oraz MacDonald 1988: 341 (tab. 2)

Kłopoty firmy Kaiser-Frazer w Stanach Zjednoczonych oraz jej stopniowe odchodzenie od produkcji samochodów wpłynęło również na jej argentyński oddział - IKA, który został w 1969 r. przejęty przez Renault, a następnie w 1975 r. formalnie przemianowany na Renault Argentina S.A. (MacDonald 1988; Belini 2006).

Wojskowy zamach stanu, który w 1955 r. obalił rządy Perona, miał również bardzo istotny wpływ na zmianę polityki w sektorze motoryzacyjnym. Złagodzono wówczas restrykcje dotyczące importu samochodów, zliberalizowano wydawanie pozwoleń na otwieranie nowych zakładów produkcyjnych, przy jednoczesnym utrzymaniu wysokiego udziału krajowych części w produkowanych pojazdach. W 1959 r. rząd prezydenta Arturo Frondiziego przyjął dekret 3.693/1959 wprowadzający nową politykę rozwoju przemysłu samochodowego. Zniesiono ograniczenia dotyczące transferu zysków przez zagraniczne koncerny. Nowe zasady inwestycji motoryzacyjnych były bardzo ogólne i nie nakładały żadnych restrykcyjnych kryteriów, które byłyby trudne do spełnienia dla firm zainteresowanych wejściem na 
argentyński rynek. W nowym rządzie panowało przekonanie, że wolna konkurencja między firmami doprowadzi do wyselekcjonowania najbardziej efektywnych i przyczyni się do wzrostu konkurencji oraz ogólnego uprzemysłowienia kraju. W odpowiedzi na wprowadzaną nową politykę zgłosiło się 26 podmiotów zainteresowanych rozpoczęciem produkcji samochodów, z których 23 złożyły stosowną dokumentację i dostały od rządu zgodę na rozwijanie produkcji, przy czym faktycznie rozpoczęło ją 21 firm (tab. 1) (Schvarzer 1995; Catalan 2010: 210; Barbero i in. 2007: 199-200).

Realizowana polityka przyniosła szybki i widoczny sukces, przejawiający się wzrostem produkcji samochodów z 32,9 tys. do 136,2 tys. sztuk w latach 1959-1961 (ryc. 4). Swoje filie produkcyjne w Argentynie otworzyło większość dużych koncernów ze Stanów Zjednoczonych i Europy (m.in. Chrysler, GM, Fiat, Ford, Citroën). Powstały też firmy oparte na rodzimym kapitale, próbujące rozwijać produkcję w oparciu o zakupione licencje. Tak duża liczba konkurujących podmiotów na stosunkowo niewielkim rynku, którego chłonność oceniano na początku lat 60 . XX w. na ok. 100 tys. pojazdów rocznie, nie sprzyjała rozwinięciu masowej produkcji i osiągnięciu odpowiednich korzyści skali. Wywołało to również silną konkurencję, która w efekcie doprowadziła do szybkiego upadku bądź przejęcia słabszych firm przez silniejsze. Dotyczyło to szczególnie małych podmiotów z rodzimym kapitałem, które nie sprostały konkurencji dużych międzynarodowych koncernów. Już w latach 1961-63 aż 10 spośród początkowych 23 firm zakończyło działalność lub zostało przejęte, a do końca lat 60 . XX w. pozostało jedynie 9 zakładów produkcyjnych (Catalano Novick 1998: 33; Barbero i in. 2007: 228; Ianni 2008: 102-103).

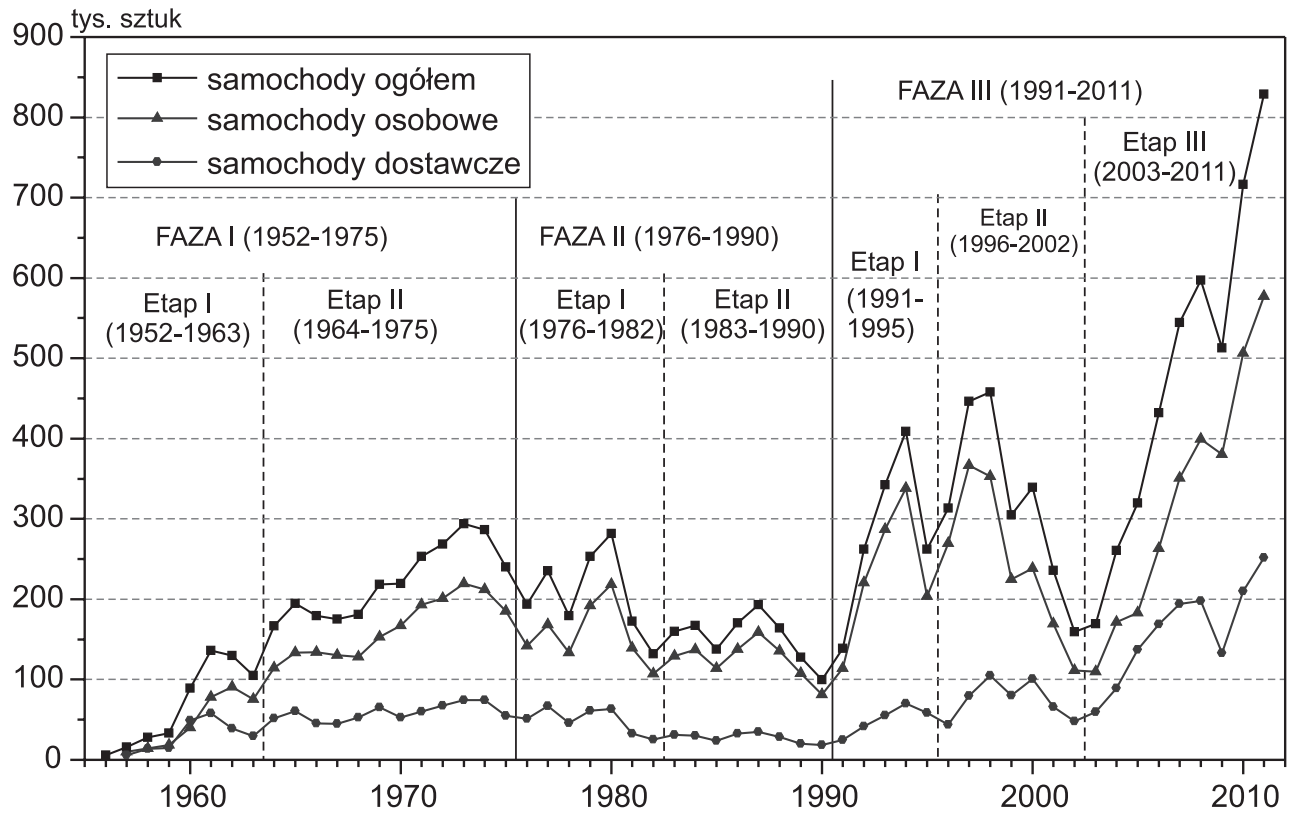

Ryc. 4. Zmiany wielkości produkcji samochodów na tle faz rozwoju przemysłu samochodowego w Argentynie w latach 1956-2011 
Dynamicznemu wzrostowi produkcji towarzyszył blisko trzykrotny wzrost zatrudnienia w tym sektorze, z 9,9 tys. do 28,2 tys. osób w latach 1959-1963. Warto jednak podkreślić, że wzrostowi produkcji i zatrudnienia nie towarzyszyło zwiększenie wydajności pracy. W $1961 \mathrm{r}$. na jednego zatrudnionego przypadało 5,6 wyprodukowanych samochodów rocznie, a w kryzysowym 1963 r. jedynie 3,1. Wskaźnik ten oscylował wokół wartości 5 pojazdów na jednego zatrudnionego przez całą dekadę lat 60. i 70. XX wieku (ryc. 5). W 1964 r. zatrudnienie w sektorze motoryzacyjnym stanowiło $11 \%$ ogółu zatrudnionych w przemyśle argentyńskim i aż 12\% zatrudnienia przemysłu przetwórczego (Barbero i in. 2007: 201).

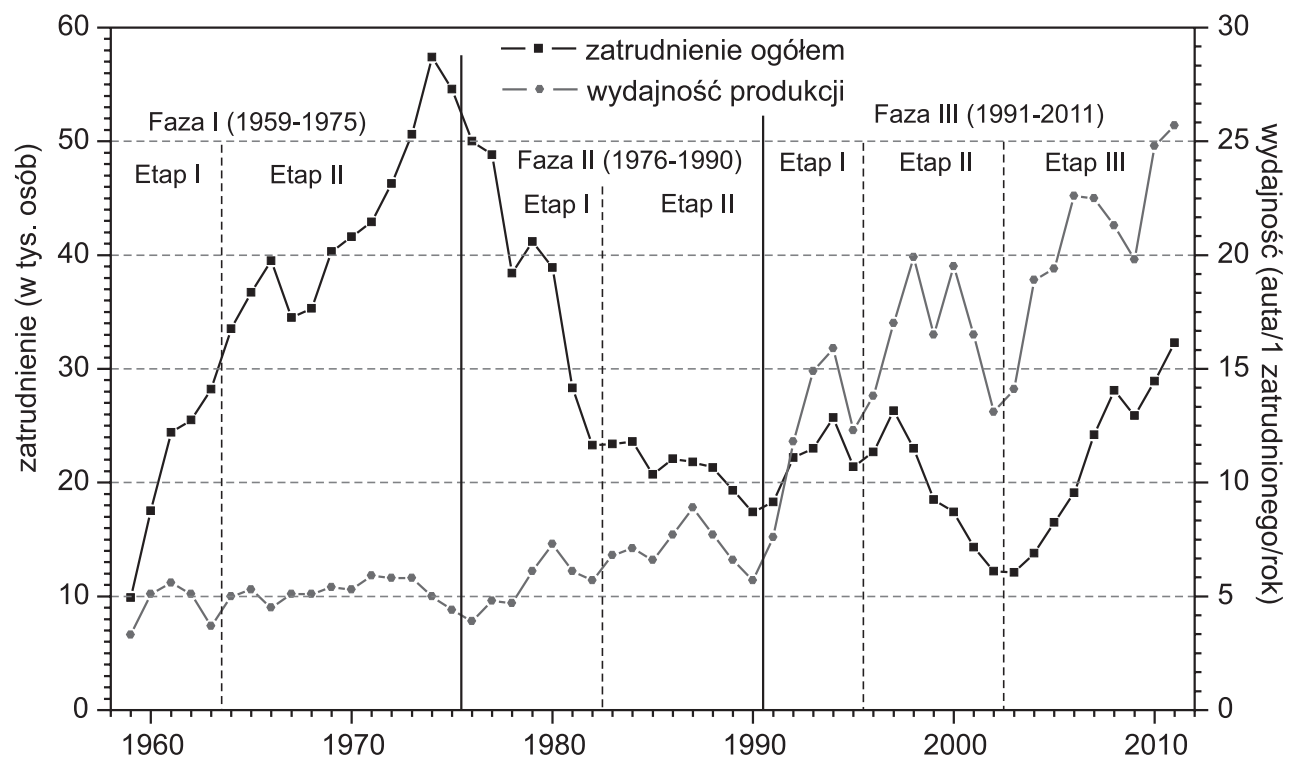

Ryc. 5. Zmiany wielkości zatrudnienia i wydajności pracy w przemyśle samochodowym Argentyny na tle faz rozwoju w latach 1959-2011

Źródło: opracowanie własne na podstawie danych Anuario ADEFA 2010, 2011

Pierwszy etap rozwoju sektora motoryzacyjnego miał również bardzo duże znaczenie dla całej gospodarki argentyńskiej, realizującej strategię przyspieszonej industrializacji. W latach 1951-1965 jego udział w PNB wzrósł z 2,5\% do 10,3\%. Natomiast w latach 19581965 wzrastał średnio o 24\% rocznie, będąc zarazem kołem zamachowym całej gospodarki (Catalano Novick 1998: 31).

Charakterystyczną cechą pierwszego etapu rozwoju rodzimego przemysłu samochodowego jest również względnie wysoka partycypacja w produkcji firm z dużym udziałem argentyńskiego rządu bądź prywatnych przedsiębiorców. Fakt, iż w pierwszym okresie produkcję rozpoczęły i zdominowały firmy IAME (IME) i IKA, z których pierwsza była w całości firmą państwową, a w drugiej większość akcji miał rząd (poprzez firmę IAME - 22\%) i prywatni drobni akcjonariusze (47\%), wskazuje na dużą rezerwę, z jaką podeszły do inwestycji główne koncerny motoryzacyjne. Warto przypomnieć, iż były one obecne na tym rynku już od okresu międzywojennego, kiedy to otworzyły montownie swoich samochodów. Jednak 
nie kwapiły się do zainwestowania w otwarcie produkcji w oparciu o miejscowe części. Dopiero zdecydowane działania rządu Juana Perona, zakończone uruchomieniem produkcji przez IAME i IKA oraz zablokowanie importu samochodów z zagranicy, uświadomiło kierownictwu koncernów, że nieuruchomienie produkcji wykluczy ich z argentyńskiego rynku motoryzacyjnego. Z drugiej strony, polityka rozwoju sektora motoryzacyjnego realizowana przez rząd Arturo Frondiziego oraz towarzyszące jej dekrety ułatwiające i zabezpieczające inwestycje zagraniczne oraz swobodny transfer zysków, dodatkowo „ośmieliły” zagraniczne koncerny i utwierdziły w przekonaniu, że poniesione koszty przyniosą oczekiwane zyski (Schvarcer 1995; Catalan 2010: 210; Catalano Novick 1998: 31; Barbero i in. 2007: 195-201).

Według dostępnych danych, do 1962 r. w ogólnej strukturze produkcji samochodów dominowały firmy państwowe bądź z dominacją prywatnego, lokalnego kapitału. W latach 50 . XX w. wytwarzały one praktycznie ponad $95 \%$ produkcji, natomiast na początku kolejnej dekady ich udział zaczął się drastycznie zmniejszać, w miarę rozwoju produkcji przez główne światowe koncerny (szczególnie „wielką trójkę z Detroit”). W tym kontekście rok 1963, wyznaczający koniec pierwszego etapu rozwoju przemysłu samochodowego, jest podwójnie ważny. Nie tylko wiąże się bowiem z gwałtownym załamaniem produkcji i upadkiem wielu małych fabryk samochodowych, ale jest również pierwszym rokiem, w którym zagraniczne koncerny zaczynają dominować w ilości wyprodukowanych samochodów (Ianni 2008: 105).

Kryzys gospodarczy, który dotknął Argentynę w latach 1962-63, doprowadził do spadku produkcji samochodów i bankructwa części zakładów, wyznaczając zarazem koniec pierwszego etapu rozwoju przemysłu motoryzacyjnego. Obejmował on okres od 1952 r., kiedy to dzięki inwestycjom państwowym uruchomiono produkcję pierwszych samochodów do 1963 r., który kończy ostrą walkę konkurencyjną między firmami chcącymi wejść na argentyński rynek. Z rywalizacji tej obronną ręką wychodzą głównie koncerny międzynarodowe, które zaczynają dominować w produkcji, stopniowo wypierając firmy państwowe oraz małe, prywatne firmy produkujące w większości pojazdy na podstawie zakupionych licencji.

Lata 1964-1975 wyznaczają drugi etap pierwszej fazy rozwoju przemysłu samochodowego, zdominowany przez procesy koncentracji i konsolidacji produkcji. Do końca tego etapu na rynku pozostało jedynie 9 koncernów międzynarodowych (Ford, GM, Chrysler, Fiat, Mercedes Benz, Renault, Citroën, Peugeot, Deutz) oraz jedna firma państwowa IME (wcześniejsze IAME). Równocześnie bardzo dynamicznie rozwijał się sektor produkcji części samochodowych, co wynikało z realizowanej polityki industrializacji poprzez substytucję importu, która wymagała od producentów samochodów osiągnięcia bardzo wysokiego udziału krajowych części w wytwarzanych pojazdach (Barbero i in. 2007: 202). Zwiększył się on z poziomu 26,3\% w $1960 \mathrm{r}$. do blisko 50\% pod koniec lat 60. XX w. (Catalano Novick 1998: 34).

Badany etap charakteryzuje się również dynamicznym wzrostem ogólnej produkcji samochodów o 280\%, z poziomu 14,9 tys. sztuk w 1963 r. do 293,7 tys. sztuk w 1973 r. (ryc. 4). Towarzyszył mu równie szybki wzrost zatrudnienia, które w latach 1963-1974 wzrosło o $203,5 \%$ z poziomu 28,2 tys. do 57,4 tys. osób, osiągając zarazem maksymalną wartość w całym analizowanym okresie. Warto jednak podkreślić, iż produkcja charakteryzowała 
się bardzo niskim stopniem automatyzacji, co wymuszało duży przyrost siły roboczej i znajdowało odzwierciedlenie w niskiej wydajności, która oscylowała w całym drugim etapie wokół 5 pojazdów rocznie na jednego zatrudnionego (ryc. 5). Firmy oferowały szeroką gamę produktów, co jednocześnie ograniczało skalę produkcji i nie pozwalało w pełni wykorzystać korzyści skali. W 1965 r. IKA produkowała 17 modeli, co w odniesieniu do ogólnej wielkości produkcji dawało średnią 3331 pojazdów jednego modelu, Ford, wytwarzający 30424 sztuk 6 modeli osiągnął średnią 5071, natomiast Fiat, z produkcją 28868 sztuk 5 modeli notował średnią 5774. Tak silne zróżnicowanie produktów nie tylko utrudniało automatyzację i umasowienie produkcji, co pozwoliłoby osiągnąć większe korzyści skali, ale także wydłużało czas produkcji, zwiększało nakłady pracy i, w obliczu silnej konkurencji, obniżało marżę zysku (Catalan 2010: 213).

Rok 1973, w którym osiągnięto rekord produkcji wynoszący 293,7 tys. sztuk, był zarazem ostatnim rokiem, w którym odnotowano jej wzrost. W kolejnym roku produkcja po raz pierwszy od $1968 \mathrm{r}$. spadła o 2,5\% w stosunku do roku wcześniejszego, zaś w 1975 była już o 18,3\% mniejsza w porównaniu z rekordowym 1973 r. (ryc. 4). W pierwszej połowie lat 70. wyraźnie zaczęła się pogarszać sytuacja międzynarodowa, co było związane z pierwszym „szokiem naftowym”. Spowolnienie gospodarcze w państwach wysokorozwiniętych wpłynęło niekorzystnie na sytuację makroekonomiczną Argentyny, pogorszyło jej bilans płatniczy i doprowadziło do nasilenia się tendencji inflacyjnych. Rosnąca inflacja zahamowała i podrożyła kredyty, co przełożyło się bezpośrednio na liczbę kupowanych nowych pojazdów, która w latach 1973-75 spadła o 20,5\%, z 285,3 tys. do 226,8 tys. sztuk (ryc. 6).

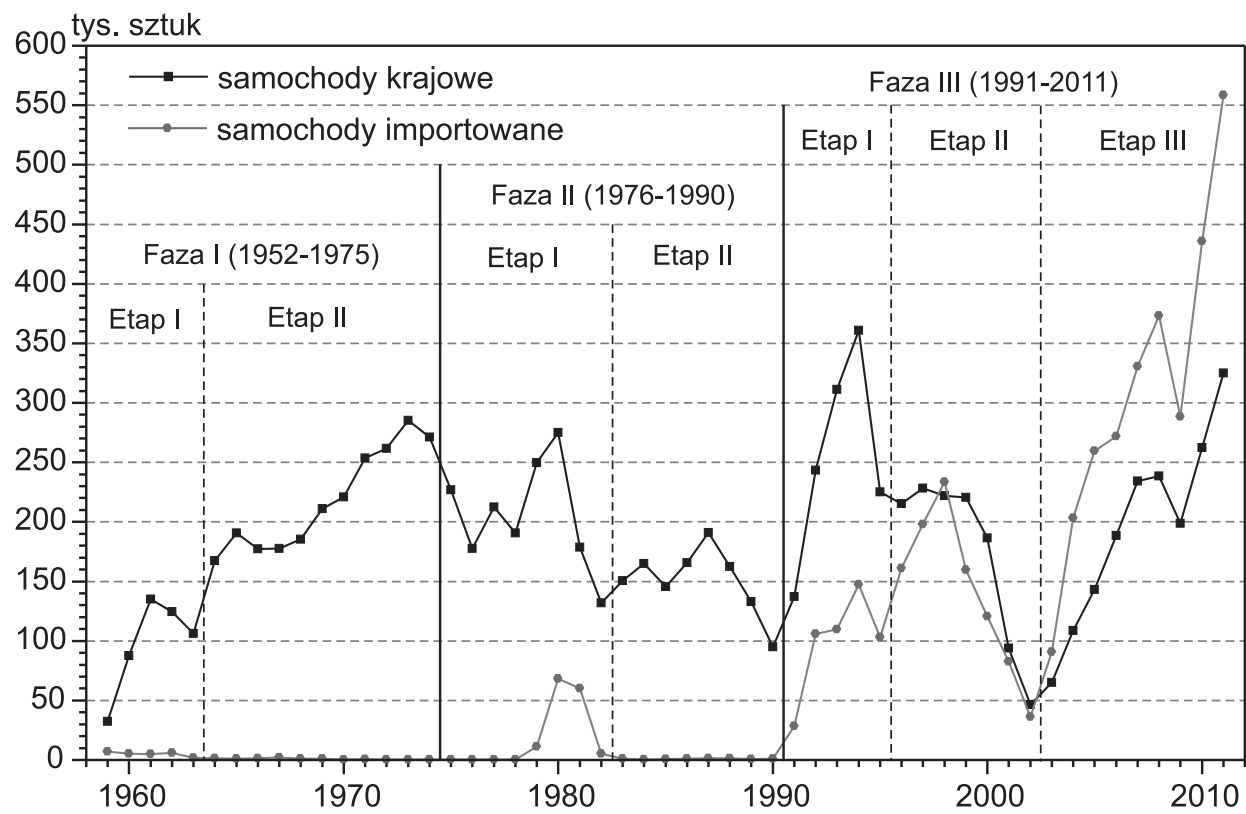

Ryc. 6. Zmiany wielkości sprzedaży samochodów krajowych i importowanych w Argentynie na tle faz rozwoju w latach 1959-2011

Źródło: opracowanie własne na podstawie danych Anuario ADEFA 2010, 2011 
Spadek popytu wewnętrznego próbowano łagodzić wzrostem eksportu, stosując różnego typu zachęty podatkowe, w celu skłonienia działających w kraju koncernów do większej aktywności na rynkach zagranicznych. Polityka ta odniosła jednak niewielki skutek, gdyż produkowane w Argentynie pojazdy nie były zbytnio konkurencyjne na rynkach światowych, zarówno ze względu na stosunkowo wysoką cenę - wynikającą z kosztów produkcji, jak i oferowany asortyment, składający się w przeważającej części z technologicznie przestarzałych modeli, które nie były w stanie konkurować z samochodami produkowanymi w państwach wysokorozwiniętych. Odsłoniło to ograniczenia i ujemne strony realizowanej strategii rozwoju tego sektora poprzez substytucję importu. Rozwijany za „zasłoną” wysokich ceł i ograniczeń importowych przemysł motoryzacyjny, okazał się mało konkurencyjny na światowym rynku. Niewielka skala produkcji i niska jej mechanizacja podnosiły koszty wytwarzanych aut, a brak udziału w światowej rywalizacji koncernów motoryzacyjnych sprawiał, że w Argentynie produkowano głównie przestarzałe modele, które w państwach rozwiniętych były wycofywane z produkcji lub zastępowane nowymi (Catalano Novick 1998; Barbero i in. 2007).

Niemniej jednak w obliczu kurczącego się rynku wewnętrznego i aktywnych zachęt proeksportowych ze strony rządu, w pierwszej połowie lat 70. XX w. koncerny samochodowe znacząco zwiększyły wartość eksportu samochodów i ich części. W latach 1970-1975 wartość eksportu wzrosła ponad dziesięciokrotnie, z 10,8 mln do 115,2 mln dolarów. Ten podwyższony poziom wartości eksportu, oscylujący pomiędzy 108 a 140 mln dolarów, utrzymał się do 1980 r., by w pierwszej połowie lat 80. ulec załamaniu (ryc. 7). Eksport pojazdów zwiększył się z 1676 sztuk w 1972 r. do 10396 sztuk w 1975 (Barbero i in. 2007: 207).

Pierwsza połowa lat 70. XX w. to okres pogarszania się sytuacji gospodarczej i politycznej w kraju. W 1973 r. po raz trzeci prezydentem został Juan Domingo Peron, który zmarł 1 lipca 1974 r., a władzę po nim przejęła jego trzecia żona - María Estela Martínez de Peron, pełniąca funkcję wiceprezydenta kraju. Polityka wewnętrzna powodowała wzrost napięć pomiędzy różnymi aktorami życia politycznego. Robotnicy byli niezadowoleni z kontroli cen przez rząd i nieskutecznej walki z inflacją. Zmienił się także stosunek władz do koncernów międzynarodowych. Nasiliły się tendencje nacjonalistyczne, większy nacisk położono na rozwój firm narodowych, wspieranych przez różne formy promocji, przy jednoczesnych restrykcjach odnośnie transferu dochodów i prowadzenia działalności, które wprowadzono w stosunku do firm z kapitałem zagranicznym. Przyjęta w 1973 r. ustawa o inwestycjach zagranicznych wprowadziła większe ograniczenia dla inwestorów, którzy nie mogli być w żaden sposób faworyzowani w porównaniu z firmami krajowymi. Ponadto, blokowała ona inwestycje zagraniczna w liczne sektory gospodarki, uznane za strategiczne oraz zakazywała zakupu firm argentyńskich przez obce koncerny (Barbero i in. 2007: 206-207).

Przejawem zmiany polityki w sektorze motoryzacyjnym był przyjęty w $1971 \mathrm{r}$. Program Restrukturyzacji Przemysłu Samochodowego (Regimen de Reconversión de la Industria Automotriz), w którego przygotowaniu dużą rolę odegrał lobbing produkujących części samochodowe firm argentyńskich, skupionych w Izbie Gospodarczej Producentów Części Samochodowych (Cámara Industrial de Fabricantes de Autopiezas - CIFARA). Przyjęty program zakładał większą ,,argentynizację" produkcji, poprzez wzrost znaczenia dostawców 
części w relacjach z koncernami produkującymi gotowe pojazdy, równocześnie zakazując importu samochodów do 1980 r. Ponadto, podjęto także próbę działań zwiększających korzyści skali (poprzez wprowadzenie zakazu produkcji nowych modeli oraz wymogów minimalnej wielkości produkowanych serii pojazdów) oraz promowano eksport (Barbero i in. 2007: 206).

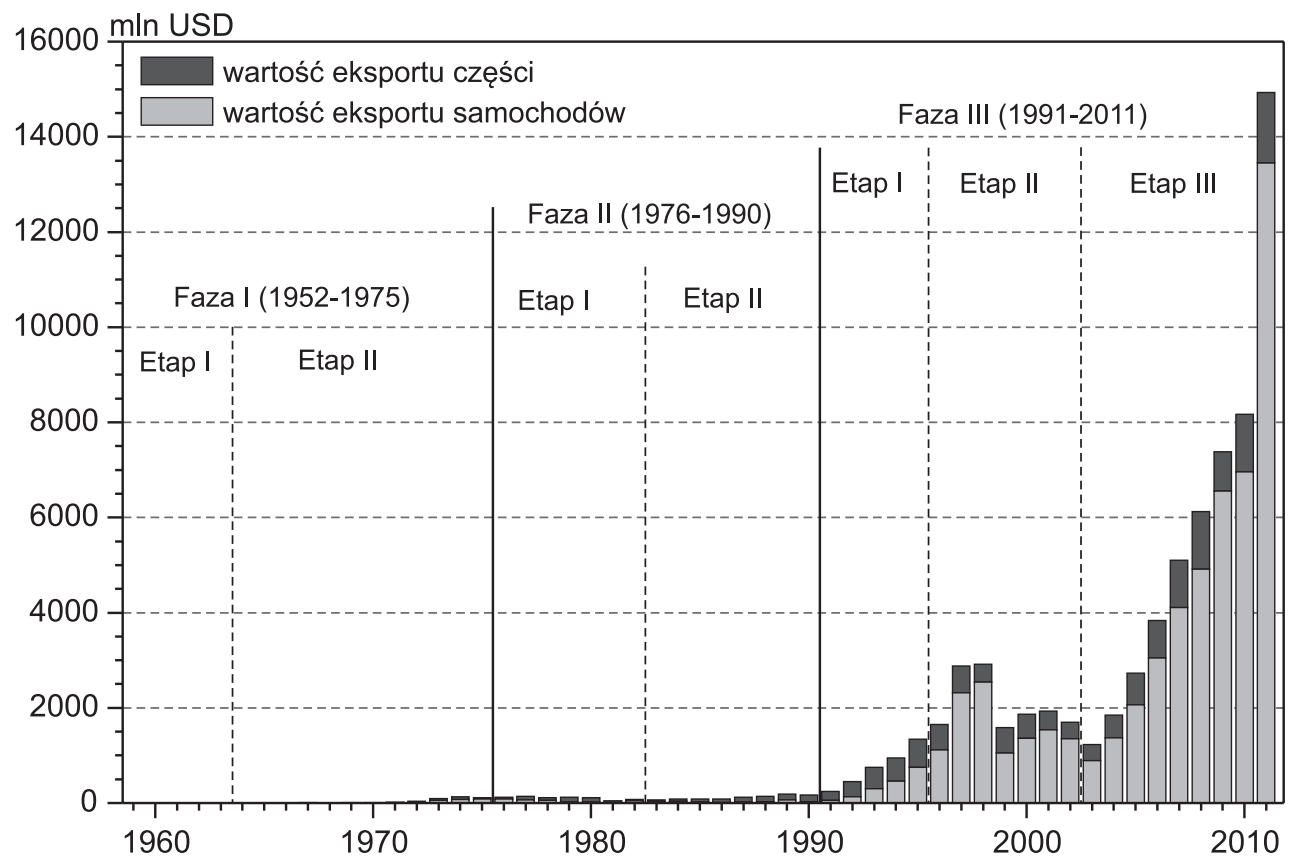

Ryc. 7. Zmiany wielkości eksportu argentyńskiego przemysłu samochodowego w latach 1959-2010

Źródło: opracowanie własne na podstawie danych Anuario ADEFA 2010, 2011

Pierwsza połowa lat 70. XX w. to zarazem ostatni okres ortodoksyjnego przestrzegania polityki rozwoju gospodarczego poprzez substytucję importu. Wprowadzane przez rząd próby miały na celu ochronę krajowego rynku pracy oraz działających na nim firm, przed pogarszającą się sytuacją ekonomiczną na świecie, wchodzącym w fazę recesji po „szoku naftowym". Nowa polityka władz nie była jednak w stanie zahamować pogarszającej się sytuacji społeczno-ekonomicznej w Argentynie, a dodatkowo uderzała w interesy koncernów zagranicznych.”Wynikiem nasilających się napięć i konfliktów był dokonany w marcu 1976 r. wojskowy zamach stanu.

\section{Faza II - kryzys i restrukturyzacja przemysłu samochodowego 1976-1990}

Rządy junty wojskowej w latach 1976-1982 dokonały zmiany paradygmatu rozwoju gospodarczego, przyjmując wzorce neoliberalne i otwierając kraj na gospodarkę światową. $\mathrm{W}$ walce $\mathrm{z}$ rosnącą inflacją stosowano standardowe rozwiązania proponowane przez 
neoliberalnych ekonomistów, polegające na ograniczaniu popytu wewnętrznego przy jednoczesnym liberalizowaniu wymiany handlowej z zagranicą. W przypadku przemysłu samochodowego rządy wojskowych zapoczątkowują nową fazę rozwojową, cechującą się głębokim kryzysem oraz próbami restrukturyzacji i poszukiwania nowego modelu rozwoju w zmieniających się realiach postępującej integracji regionalnej i globalizacji. Obejmowała ona lata 1976-1990 i - podobnie jak w poprzedniej fazie - można w jej obrębie wyróżnić dwa etapy. Pierwszy z nich, wyznaczony przez okres rządów wojskowych (1976-1982), cechuje się generalnie załamaniem wielkości produkcji oraz towarzyszącej jej silnej redukcji zatrudnienia w tym sektorze, jak również „ucieczką” z kraju kilku koncernów motoryzacyjnych, które zrezygnowały z kontynuowania produkcji. Drugi etap obejmuje okres od 1983 r. do 1990 r., kiedy to sektor przechodził restrukturyzację produkcji i próbował dostosować się do nowych warunków w ramach pogłębiającej się globalizacji oraz rozwijającej się współpracy regionalnej z Brazylią (Catalano Novick 1998: 34; Barbero i in. 2007: 208-210).

Polityka przemysłowa rządu wojskowych miała bardzo duży wpływ na kryzys, jaki dotknął ten sektor w końcu lat 70. XX w. Zniósł on zakaz importu samochodów i ustalił cła na samochody osobowe na poziomie 95\%, zaś w przypadku użytkowych 65\% ich wartości, które obowiązywały do 1979 r. W kolejnych latach stopniowo je obniżano, aż do poziomu odpowiednio: 55\% i 45\% wartości w 1982 r. Równolegle zezwolono na wzrost udziału części importowanych w produkowanych pojazdach i eliminowano restrykcje w wertykalnej integracji producentów samochodów z firmami dostarczającymi podzespoły. Ponadto, wojskowe władze otworzyły również możliwość wejścia na rynek argentyński nowych firm, szczególnie dostawców części, kooperujących z międzynarodowymi koncernami samochodowymi w ramach tworzących się globalnych łańcuchów wartości (global value chains) (Catalano Novick 1998: 34).

Produkcja samochodów w pierwszym etapie drugiej fazy rozwoju wykazywała duże wahania, jednak generalnie dominowała tendencja spadkowa, ze 193,5 tys. sztuk w 1976 r. do 132,1 tys. sztuk w 1982 r. Towarzyszyła jej przy tym drastyczna redukcja zatrudnienia w tym sektorze, z 50,0 tys. do 23,3 tys. osób, czyli aż o 53,5\%, co nieznacznie podniosło wydajność pracy do ok. 7 pojazdów na jednego zatrudnionego na rok (ryc. 4 i 5). Wprowadzona w 1979 r. ustawa nr. 21932 kończyła definitywnie politykę substytucji importu i znosiła ograniczenia dotyczące importu części, jak i gotowych pojazdów, co uruchomiło napływ aut z zagranicy. W krótkim okresie sprzedaż sprowadzanych samochodów wzrosła z 458 sztuk w 1978 r. do 68,4 tys. sztuk w 1980 r., co stanowiło 19,9\% całkowitej sprzedaży nowych samochodów w tym roku (ryc. 6). Gwałtownie zwiększył się również import części - z 460 sprowadzanych w 1978 r. do 68 tys. w 1980 r., co pokrywało 20\% zapotrzebowania krajowych producentów (Barbero i in. 2007: 209).

Spadek wielkości produkcji, wywołany ograniczeniem sprzedaży krajowej oraz spadkiem eksportu przy jednoczesnym wzroście kosztów produkcji, gwałtownie pogorszył sytuację finansową przedsiębiorstw, doprowadzając część z nich do podjęcia decyzji o likwidacji swoich zakładów w Argentynie. W 1978 r. udział General Motors w rynku argentyńskim spadł do 2\% w porównaniu do 8\% w 1976 r. Firma odnotowała dużą stratę finansową i zdecydowała się zamknąć swoją działalność w Argentynie. W 1979 r. Chrysler, Citroën i Deutz 
- producent ciężarówek, decydują się zakończyć produkcję. Natomiast w 1980 r. w ramach Procesu Reorganizacji Kraju (Proceso de „Reorganización Nacional”), na prośbę ministra gospodarki Martineza de Hoz, przyjęto dekret 1448/80 o zamknięciu państwowego koncernu IME S.A. (Industrias Mecánicas del Estado). Zatrudniała ona wówczas ponad 3000 pracowników, a najpopularniejszy produkowany przez nią model pick-up Rastrojero Diesel miał $78 \%$ udziału w krajowym rynku tego typu pojazdów. Inną strategią podejmowaną przez koncerny w obliczu kurczącego się rynku były fuzje i rozwijanie wspólnej produkcji. Pierwszą z nich zawiązały Fiat i Peugeot, tworząc w 1980 r. spółkę SEVEL S.A. (Sociedad Europea de Vehículos para Latinoamérica). Przetrwała ona do 1995 r., kiedy Fiat zdecydował się przejąć nad nią pełną kontrolę i wybudował nową fabrykę w mieście Cordoba, która zainaugurowała działalność w grudniu 1996 r., pod nazwą Fiat Auto Argentina. Kolejną lokalną fuzją była Autolatina - spółka Volkswagena i Forda, obejmująca ich argentyńskie i brazylijskie odziały, funkcjonująca w latach 1987-1996 (Barbero i in. 2007: 209; Schvarzer 1995: 5-11).

Kurczący się argentyński rynek motoryzacyjny i gwałtowny spadek eksportu na początku lat 80 . XX w., wymusiły na koncernach nie tylko większą integrację, racjonalizację zatrudnienia i zmniejszenie ilości oferowanych modeli, ale także automatyzację i robotyzację produkcji oraz zacieśnienie współpracy z dostawcami części (Catalano Novick 1998: 37-38).

Drugi etap wiąże się z dojściem do władzy z końcem 1983 r. nowego prezydenta - Raúla Alfonsa - wybranego w demokratycznych wyborach. Polityka w stosunku do sektora motoryzacyjnego niewiele się zmieniła, ponieważ kraj znajdował się w trudnej sytuacji gospodarczej, borykając się z obsługą dużego zadłużenia zagranicznego i walcząc z hiperinflacją. Nie dysponował on żadnymi środkami finansowymi, które można by przeznaczyć na aktywną politykę wspierającą ten sektor. Firmy, które przetrwały kryzys pierwszej połowy lat 80. XX w., nadal nie mogły przywrócić trwałej zyskowności produkcji w swoich fabrykach (Catalan 2010: 220). Zmuszone były nadal przeprowadzać działania restrukturyzacyjne, redukować zatrudnienie, wprowadzać system dostaw ,just in time" oraz zarządzanie jakością produkcji. Od 1986 r., kiedy to rozpoczęły się rozmowy o integracji gospodarczej z Brazylią, polityka koncernów samochodowych uległa zmianie. Zaczęły one wprowadzać większą specjalizację produkcji. Te z nich, które miały fabryki w obu krajach, starały się, aby ich produkcja stała się komplementarna względem siebie, co pozwalało osiągnąć większe korzyści skali. Taka strategia przyczyniła się do wzrostu wartości eksportu, szczególnie części samochodowych (Barbero i in. 2007: 211). W 1989 r. osiągnął on wartość 186,8 mln USD, w czym 66,6\% stanowiły właśnie części (ryc. 7).

W drugiej połowie lat 80 . XX w. nadal notowano spadek produkcji krajowej, która w latach 1987-1990 obniżyła się ze 193,3 tys. do 99,6 tys. sztuk, co było poziomem najniższym od 1960 r. Podobny spadek odnotowano w przypadku sprzedaży nowych pojazdów, która w 1990 r. wyniosła zaledwie 96 tys. sztuk, czyli wartość porównywalną z rokiem 1960 (por. ryc. 4 i 6). Załamaniu produkcji i sprzedaży krajowej towarzyszyła dalsza redukcja zatrudnienia, które spadło do poziomu 17,4 tys. osób i było o $25,1 \%$ niższe w porównaniu z 1982 r. Podjęte działania - mające zwiększyć automatyzację i mechanizację produkcji oraz przyczynić się do podniesienia wydajności - znalazły nieznaczne odzwierciedlenie we wzroście wartości wskaźnika wydajności pracy. W 1987 r. wyniósł on prawie 9 sztuk na 
jednego zatrudnionego na rok. Jednakże, w wyniku ograniczania produkcji w kolejnych latach, w 1990 roku znów wrócił do niecałych 6 sztuk na zatrudnionego (ryc. 5). Na tej podstawie można więc stwierdzić, iż dokonane w dekadzie lat 80. zabiegi - mające zwiększyć efektywność produkcji, którym jednak nie towarzyszyły żadne duże inwestycje w modernizację i przebudowę zakładów oraz linii produkcyjnych - nie przyniosły znaczącej poprawy wydajności.

\section{Faza III - odbudowa i reorganizacja przemysłu samochodowego 1991-2011}

Początek lat 90. XX w. wyznacza nową fazę rozwoju argentyńskiego przemysłu samochodowego. Wynika to z faktu, iż w tym okresie podjęto zdecydowane działania reformujące politykę gospodarczą kraju, wprowadzono nowy program rozwoju dla tego sektora przemysłu oraz zacieśniano współpracę regionalną z Brazylią, poszerzając tym samym rynek zbytu dla produkowanych pojazdów. Zmieniło to znacząco realia funkcjonowania i dalszego rozwoju przemysłu samochodowego oraz przyczyniło się do jego wyraźnego rozwoju. W fazie tej zaznaczają się lata załamania produkcji, wyznaczające granice trzech etapów rozwoju. Pierwszy z nich obejmuje lata 1991-1995, kolejny 1996-2002, zaś trzeci trwa od 2003 do chwili obecnej (ryc. 4).

Pierwszy etap rozwoju (1991-1995) charakteryzowała odbudowa i reorganizacja argentyńskiego sektora samochodowego, wpisująca się w szerszy plan reform gospodarczych, starających się wyciągnąć kraj z trwającej w latach 80. stagnacji. W kwietniu 1991 r. przyjęto ustawę o konwergencji, która ustalała stały kurs wymiany peso na dolary i przyczyniła się do aprecjacji argentyńskiej waluty. Poprawiło to sytuację makroekonomiczną kraju, przyczyniając się do opanowania inflacji i przywrócenia akcji kredytowej oraz wzrostu konsumpcji. Wprowadzana neoliberalna polityka gospodarcza redukowała także udział państwa w gospodarce i zmniejszała deficyt budżetowy, zachęcając do napływu kapitały zagraniczne. W 1992 r. wszedł w życie dekret nr 2677/91, wprowadzający nową politykę w przemyśle samochodowym. Jej celem była restrukturyzacja oraz racjonalizacja działania tego sektora, a także wprowadzenie zestawu stabilnych ,reguł gry”, które redukowałyby niepewność i zachęcały do nowych długofalowych inwestycji. Zakładała ona działania na trzech płaszczyznach. Na płaszczyźnie polityki dochodowej miała ona stymulować wzrost sprzedaży krajowej, poprzez obniżenie cen pojazdów, w wyniku redukcji podatków nakładanych na producentów, ustalenia długofalowej polityki stabilizowania wzrostu wynagrodzeń, jak również obniżenia prowizji od sprzedaży części samochodowych przez producentów pojazdów oraz dealerów. Na płaszczyźnie produkcji przemysłowej producenci deklarowali modernizację swoich zakładów i wprowadzenie do produkcji najnowszej generacji pojazdów, a także ograniczenie ilości produkowanych modeli w celu osiągnięcia korzyści skali i większej specjalizacji. $\mathrm{Na}$ ostatniej z płaszczyzn, tj. wymiany zagranicznej, zezwolono na przejściowy import gotowych pojazdów, aby zapewnić koncernom zyski potrzebne do sfinalizowania nakładów inwestycyjnych i transformacji produkcji. Natomiast w późniejszym okresie firmy mające fabryki w Argentynie mogły sprowadzać samochody swojej marki z zagranicy, płacąc cło 
w wysokości jedynie 2\% wartości - jeżeli osiągały porównywalną wartość importu swoich pojazdów, bądź części - co miało zapobiegać powstawaniu nierównowagi w handlu zagranicznym. Ta polityka miała prowadzić do osiągnięcia dwóch celów. Po pierwsze, wspierania firm specjalizujących się w produkcji ograniczonej liczby modeli, co pozwalało im uzupełnić gamę oferowanych pojazdów importem z zagranicy. Po drugie, starano się zachęcić nowe koncerny do otwarcia fabryk w kraju i korzystania z niskich stawek celnych (Miozzo 2000: 657; Barbero i in. 2007: 213-214).

W 1991 r. na mocy traktatu z Asunción powstało regionalne ugrupowanie gospodarcze - Wspólny Rynek Południa (Mercado Común del Sur - Mercosur), zrzeszające poza Argentyną także Brazylię, Paragwaj i Urugwaj, a od 2006 r. również Wenezuelę. Powstanie Mercosur było drugim czynnikiem zmieniającym uwarunkowania rozwoju argentyńskiego sektora samochodowego, ponieważ aż 5-krotnie zwiększało wielkość potencjalnego rynku zbytu. Ponadto, sąsiednia Brazylia była jednym z najdynamiczniej rozwijających się rynków samochodowych na świecie, do którego w myśl podpisanych porozumień, argentyńskie fabryki uzyskiwały uprzywilejowany dostęp. W opinii argentyńskich badaczy, utworzenie Mercosur, które zwielokrotniło wielkość regionalnego rynku motoryzacyjnego i stworzyło możliwości komplementarnego rozwoju produkcji przez fabryki koncernów międzynarodowych zlokalizowanych w obu krajach, było decydującym czynnikiem przemawiającym za masowym napływem nowych inwestycji w tym sektorze (Barbero i in. 2007: 214).

W latach 1994-1997 powróciły do Argentyny koncerny Chrysler (1996) oraz General Motors (1993), natomiast Fiat w 1995 r. zdecydował się przejąć kontrolę nad swoją argentyńską filią i zainwestował $600 \mathrm{mln}$ USD w budowę nowej fabryki na przedmieściach miasta Cordoba, która rozpoczyna działalność w grudniu 1996 r. pod nazwą Fiat Auto Argentina. Nowym koncernem, który zdecydował się wejść na ten rynek w 1993 r., była Toyota, która wybudowała zakład produkcyjny w mieście Zarate, na północny-zachód od Buenos Aires, a w 1996 r. rozpoczęła produkcję modelu pick-up Hilux (Barbero i in. 2007: 215; Aliberti i in. 2010: 14).

Francuskie koncerny motoryzacyjne, które opuściły ten kraj (jak Citroën i Peugeot), czy ograniczyły swoją działalność (jak Renault) na fali procesu internacjonalizacji produkcji oraz jej delokalizacji do państw i regionów stających się ,wschodzącymi” rynkami motoryzacyjnymi, również ponownie pojawiły się w Argentynie (Dorocki 2010; Lizak 2012). Renault w 1997 r. przejął kontrolę nad swoim oddziałem, który w latach 1992-1997 nosił nazwę CIADEA (Compañia Interamericana de Automóviles), a jej większościowym udziałowcem była argentyńska grupa przemysłowa. W 1997 r. powraca także do Argentyny koncern PSA (Peugeot-Citroën), przejmując 15\% akcji firmy Sevel Argentina. W kolejnym roku zwiększył swoje udziały do 50\%. Natomiast w 1999 r. przejął pełną kontrolę nad firmą i rozwinął produkcję nowych modeli (Barbero i in. 2007: 215; Aliberti i in. 2010: 6-20).

W pierwszym etapie trzeciej fazy rozwoju, obejmującym lata 1991-1995, odnotowano ponad 4-krotny wzrost produkcji samochodów, z 99,6 tys. (1990) do 408,8 tys. (1994), któremu towarzyszyło zwiększenie zatrudnienia zaledwie o 47,7\%, z 17,4 tys. do 25,7 tys., co wyraźnie podniosło wskaźnik wydajności pracy z 5,7 do 15,9 pojazdów na jednego zatrudnionego rocznie (ryc. 4 i 5). Potwierdza to tym samym sukces wprowadzanej przez rząd 
strategii rozwoju tego sektora, gdyż z jednej strony osiągnięto rekordową wielkość produkcji, zaś z drugiej w końcu udało się podnieść efektywność i wydajność argentyńskich fabryk, co było przedmiotem politycznych zabiegów już od końca lat 70. XX w.

Wprowadzana polityka gospodarcza ustabilizowała sytuację w kraju, zatrzymała inflację i ożywiła konsumpcję, co było szczególnie widoczne w przypadku sprzedaży nowych samochodów. Wzrosła ona ponad pięciokrotnie w latach 1990-1994, z 96 tys. do 508,2 tys. sztuk. Pomimo faktu, iż sprzedaż krajowych modeli osiągnęła w 1994 r. rekordową wielkość 360,7 tys. sztuk, aby zaspokoić popyt sprowadzono w tym roku ponad 147,4 tys. aut, co stanowiło 29\% ogółu sprzedaży (ryc. 6). Gwałtownemu wzrostowi importu towarzyszył równie szybki przyrost wartości eksportu, który w latach 1990-1995 wzrósł ze 166,1 mln do 1339,3 mln USD (ryc. 7). Zmieniła się także struktura eksportu tego sektora. O ile na początku tego okresu eksport gotowych pojazdów stanowił zaledwie $15 \%$ ogólnej wartości eksportu tego sektora, to w 1995 już 56,3\%, co znalazło odzwierciedlenie w ilościowym wzroście eksportowanych pojazdów z 1,1 tys. do 52,7 tys. sztuk w latach 1990-1995. Mimo to sektor samochodowy notował znaczący deficyt w wymianie handlowej z zagranicą. W 1994 r. wyniósł on aż 2,4 mld USD, zaś w 1995 r. - na skutek krótkotrwałego kryzysu gospodarczego i spadku sprzedaży nowych aut - spadł do 1 mld USD. Wyraźnie zaznaczyła się również rosnąca współpraca w obrębie Mercosu, a szczególnie Brazylii, której udział w argentyńskim eksporcie przemysłu samochodowego wzrósł z 35\% (1990) do 90\% (1995) (Foreign Investment in Latin America and the Caribbean 1998 1999).

W 1995 r. doszło do krótkotrwałego załamania produkcji oraz sprzedaży samochodów, wynikającego z problemów gospodarczych kraju, związanych z kryzysem finansowym, który wybuchł w Meksyku na przełomie 1994 i 1995 r.; zwanym potocznie efektem tequili (efecto tequila). W przypadku Argentyny wiązał się on z odpływem kapitałów zagranicznych, przestraszonych możliwością „rozlania się” kryzysu na kolejne kraje. Rząd starał się jednak utrzymać dodatnie saldo rachunków obrotów kapitałowych, głównie poprzez sprzedaż za granicą rządowych papierów dłużnych. Negatywne skutki efektu tequili okazały się na szczęście krótkotrwałe, gdyż już w drugiej połowie 1995 r. zagraniczni inwestorzy zaczęli wracać do Argentyny. Jednakże doszło do niebezpiecznego przesunięcia w strukturze ich inwestycji, które w coraz większym stopniu lokowali w zakup rządowych papierów dłużnych (Żuławska 2004: 79-81).

Kryzys wywołany efektem tequili wyznacza drugi etap w trakcie trzeciej fazy rozwoju przemysłu samochodowego, obejmujący lata 1995-2002. Cechował się on dużą dynamiką przemian polityczno-ekonomicznych w kraju, zakończonych głębokim kryzysem gospodarczym i walutowym, którego „dno” osiągnięto na początku 2002 r. (Żuławska 2004: 82-89). Znalazło to odzwierciedlenie we fluktuacjach wielkości produkcji, zatrudnienia oraz handlu międzynarodowego, jakie przeżywał w tym okresie przemysł samochodowy. Ważnym elementem, wpływającym na sytuację w tym sektorze było również wejście w życie w $1995 \mathrm{r}$. porozumienia o integracji gospodarczej w ramach Mercosur oraz przyjęcie dekretu 2278/94 (de autoparte ,,regional”), w myśl którego - przy obliczaniu obowiązkowego udziału krajowych części w produkowanych pojazdach - części produkowane w Brazylii uznawano za miejscowe (Miozzo 2000: 661-662; Barbero i in. 2007: 217-218). 
W analizowanym etapie odnotowano gwałtowne zmiany wielkości produkcji. W pierwszej jego części, obejmującej lata 1995-1998, wzrosła ona o 74,5\%, z 262,4 tys. do 457,9 tys. sztuk, by następnie spaść o 65,2\% do poziomu 159,4 tys. sztuk w 2002 r. (ryc. 4). Dynamiczny wzrost produkcji w pierwszym okresie wynikał głównie ze zwiększenia eksportu samochodów oraz części do Brazylii, z poziomu 1 339,3 mln USD do 2 917,7 mln USD, z czego aż 87,0\% stanowił eksport gotowych pojazdów (ryc. 7). Jednakże kryzys gospodarczy w Brazylii, który wybuchł w 1999 r., a następnie przeniósł się do Argentyny, doprowadził do gwałtownego zmniejszenia produkcji, wynikającego głównie z załamania na rynku wewnętrznym, na którym sprzedaż aut spadła z 455,4 tys. w 1998 r. do 82,3 tys. sztuk w 2002 r. Warto również zaznaczyć, że nawet w 2002 r. samochody krajowe stanowiły jedynie 56,3\% ogółu sprzedaży (ryc. 6).

Cechą charakterystyczną tego etapu jest również gwałtowny spadek zatrudnienia w tym sektorze, które obniżyło się z 26,3 tys. (1997) do 12,2 tys. osób (2002), czyli do poziomu niewiele wyższego od notowanego w 1959 r. Spadek zatrudnienia wpłynął jednak na poprawę wskaźnika wydajności pracy, który w 1998 i 2000 r. osiągnął poziom blisko 20 pojazdów na jednego zatrudnionego rocznie (ryc. 5). Wynikało to z jednej strony z uruchomienia w drugiej połowie lat 90 . XX w. nowych fabryk produkcyjnych bądź też modernizacji istniejących zakładów, a z drugiej złożyła się na to także modernizacja procesu produkcji i współpracy z kooperantami (Albornoz Yoguel 2004: 629-635).

Ostatni etap trzeciej fazy rozwoju, obejmujący lata 2003-2011, cechuje się bezprecedensowym wzrostem zarówno wielkości produkcji, jak i sprzedaży oraz handlu zagranicznego, jakie odnotował sektor samochodowy. Produkcja wzrosła ponad pięciokrotnie, ze 159,4 tys. do 828,8 tys. sztuk (ryc. 4). Sprzedaż krajowa zwiększyła się ponad dziesięciokrotnie, z 82,3 tys. do 855,5 tys. sztuk, przy czym warto zaznaczyć, iż w całym tym etapie dominowały pojazdy importowane, których liczba w 2011 r. przekroczyła 530,7 tys. sztuk, czyli aż $62 \%$ ogółu kupowanych aut (ryc. 6). Wzrost produkcji był uwarunkowany nie tylko popytem wewnętrznym, ale także dynamicznym zwiększeniem eksportu. Liczba pojazdów wysyłanych za granicę zwiększyła się ze 108 tys. (2003) do 506,7 tys. sztuk (2011), co wskazuje, iż na eksport przeznaczono aż 61,1\% całkowitej produkcji w tym roku (por. ryc. 4 i 8). Wartość eksportu osiągnęła w 2011 r. poziom 14,9 mld USD, z czego 13,4 mld USD stanowił eksport gotowych pojazdów, a 1,5 mld USD przypadało na części samochodowe (ryc. 7).

W warunkach postępującej integracji brazylijskiego i argentyńskiego przemysłu motoryzacyjnego, w ramach Mercosur dokonała się jego wyraźna specjalizacja, przejawiająca się tym, iż argentyńskie fabryki samochodowe specjalizują się $\mathrm{w}$ produkcji samochodów większych, bardziej luksusowych oraz użytkowych, w których odpowiednie korzyści skali można osiągnąć przy niższym poziomie produkcji. Natomiast brazylijskie fabryki bardziej wyspecjalizowały się w masowej produkcji mniejszych i tańszych pojazdów o pojemności silnika do 1000 lub $1400 \mathrm{~cm}^{3}$, na które jest duże zapotrzebowanie na bardzo chłonnym miejscowym rynku. Ich produkcja była szczególnie wspierana odpowiednimi programami rządowymi (Miozzo 2000; Catalano, Novick 1998; Wójtowicz 2008). Znalazło to swoje potwierdzenie w strukturze argentyńskiego eksportu, w której coraz większą rolę odgrywają pojazdy użytkowe, w tym głównie lekkie samochody dostawcze (light commercial vehicles - LCV). Generalnie ich udział wynosi ok. 1/3 ogółu eksportowanych pojazdów, jednakże 
w niektórych latach przekroczył nawet liczbę eksportowanych samochodów osobowych (ryc. 8).

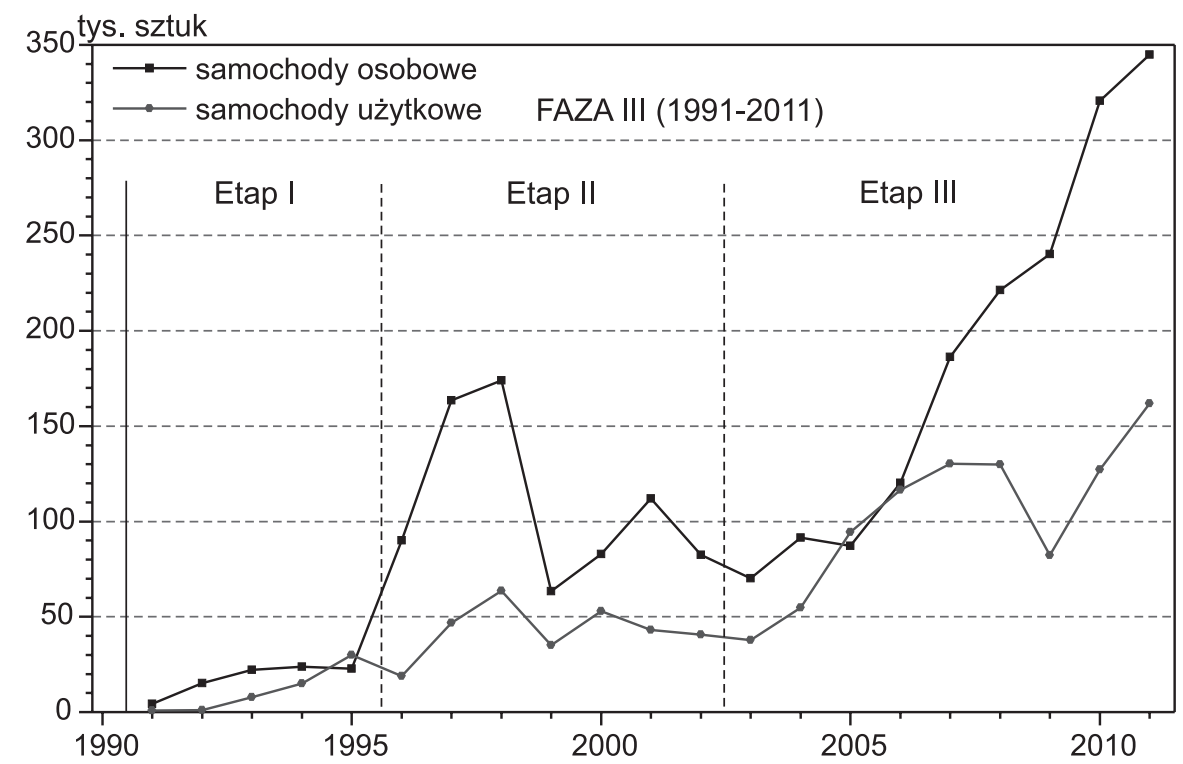

Ryc. 8. Zmiany liczby eksportowanych samochodów z Argentyny w latach 1991-2011

Źródło: opracowanie własne na podstawie Anuario ADEFA 2010, 2011

Odnotowane w ostatnim etapie III fazy zwiększenie produkcji wywołało ponowny wzrost zatrudnienia, z 12,1 tys. (2003) do 32,3 tys. osób w 2011 r. Nie wpłynęło to jednak na pogorszenie wartości wskaźnika wydajności pracy, a wręcz przeciwnie. Uległ on wyraźnej poprawie, osiągając w 2011 r. rekordową wielkość 25,7 sztuk na jednego zatrudnionego rocznie (ryc. 5).

Tak dynamiczny rozwój sektora samochodowego w ostatnim okresie skłonił do napływu nowych inwestycji oraz międzynarodowych koncernów. Ostatnim z takich przykładów jest pojawienie się w Argentynie drugiego z głównych japońskich producentów Hondy, który realizując od lat strategię internacjonalizacji produkcji wchodzi na nowe rynki. W 1997 r. otworzył on nowoczesną fabrykę samochodów w mieście Sumare w stanie São Paulo w Brazylii (Kilar, Cieluch 2010). Utrwalając i poszerzając swoją obecność na rynkach państw Mercosur, zdecydował się na budowę nowej fabryki w Argentynie w mieście Campana, w prowincji Buenos Aires (ok. 75 km na północny-zachód od stolicy), w sąsiedztwie miasta Zarate, będącego siedzibą zakładów Toyota (ryc. 9). Inwestycja w wysokości ok. 250 mln USD zakończyła się oddaniem do użytku w 2011 r. nowoczesnego zakładu o możliwościach produkcyjnych 30 tys. sztuk, w którym produkuje się model Honda City na rynek Mercosur (Anuario ADEFA 2010 2011). 


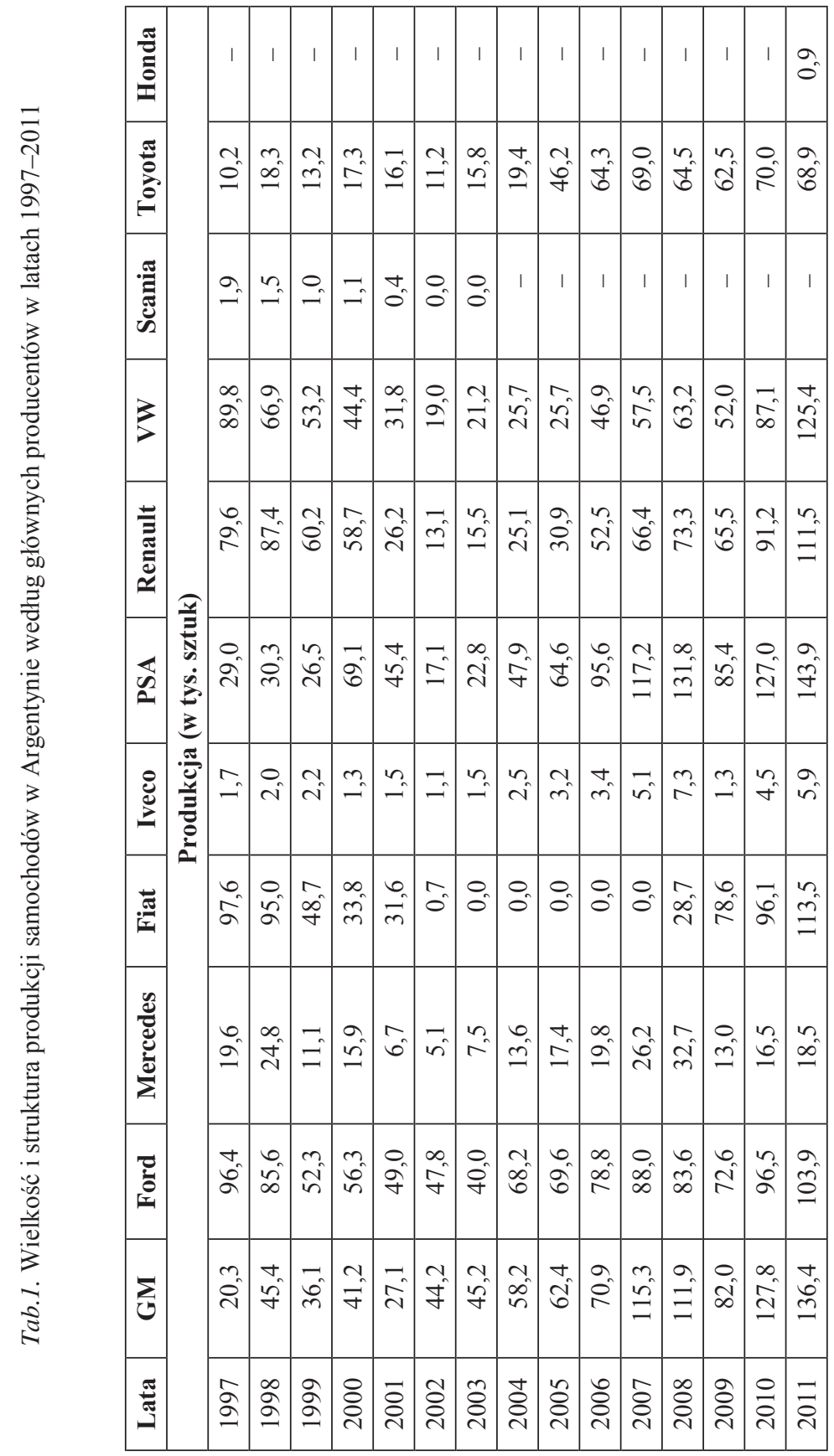




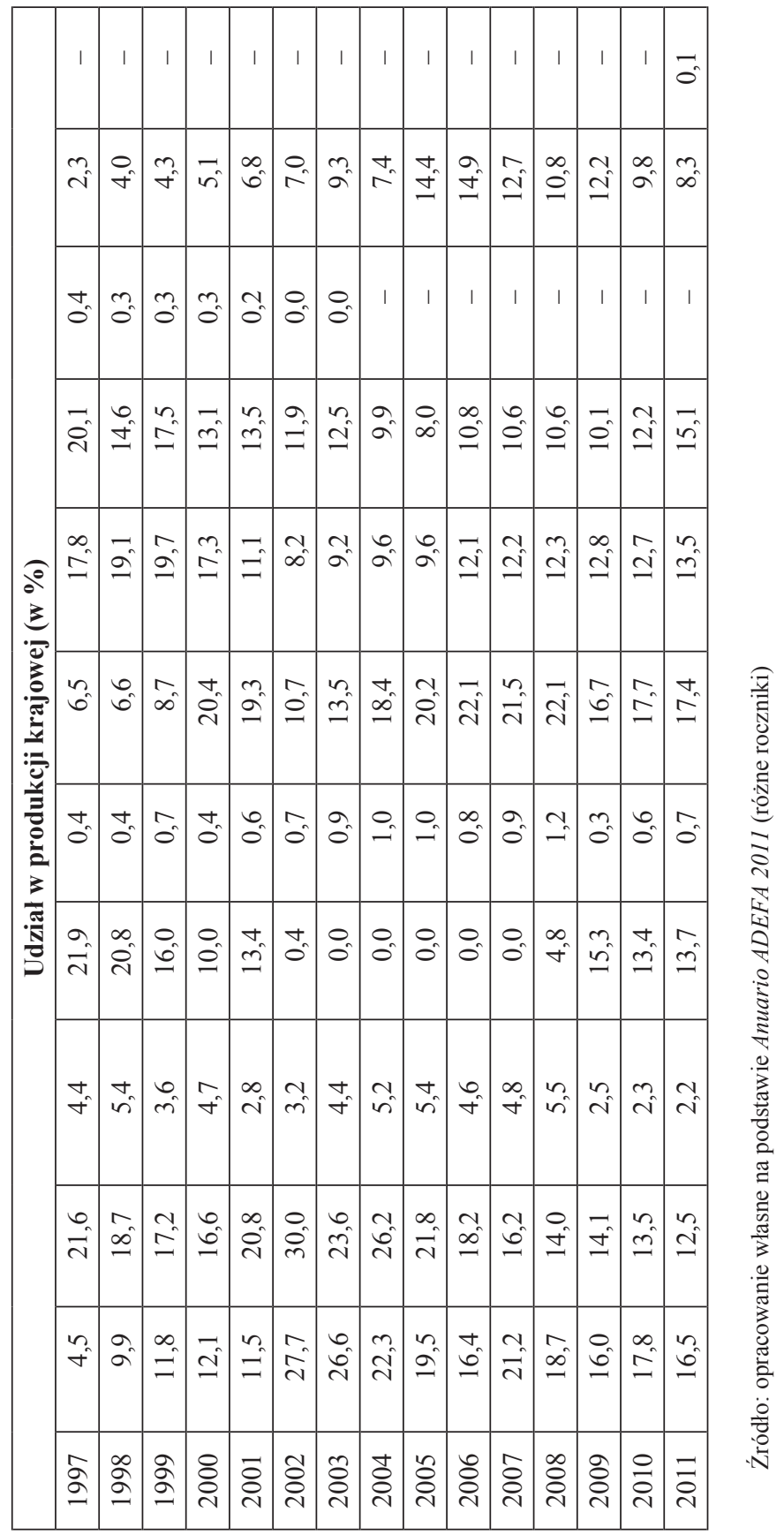




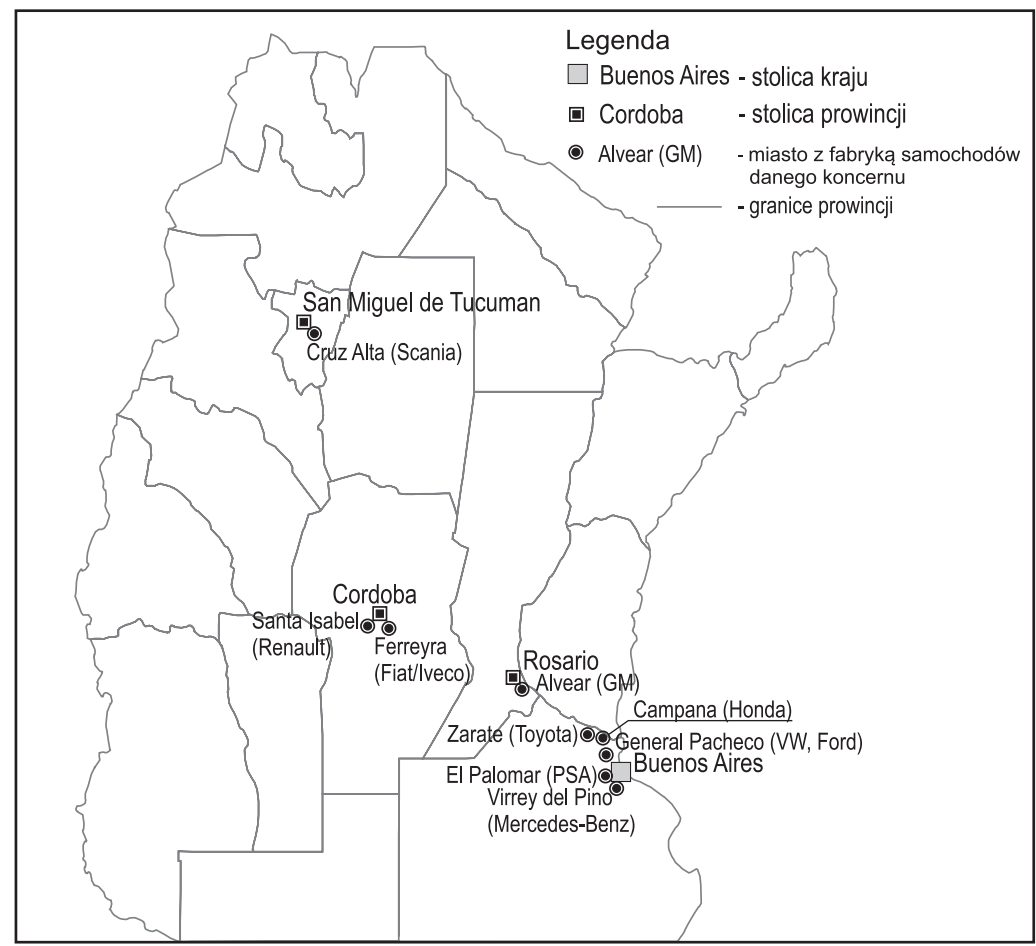

Ryc. 9. Rozmieszczenie fabryk samochodów w Argentynie w 2011 r.

Źródło: opracowanie własne na podstawie Anuario ADEFA 20102011

W 2011 r. na argentyńskim rynku działało 11 międzynarodowych koncernów samochodowych. Większość fabryk koncentruje się w sąsiedztwie bądź w obrębie obszaru metropolitalnego Buenos Aires. Drugim ważnym ośrodkiem koncentracji tego przemysłu jest miasto Cordoba, w którym powstały jedne z pierwszych zakładów produkcyjnych w kraju, a obecnie znajdują się w nim - bądź na jego przedmieściach - nowoczesne fabryki koncernów Fiat, Iveco i Renault (ryc. 9).

W 2011 r. największy udział w produkcji samochodów w Argentynie miały głównie koncerny europejskie: PSA Peugeot-Citroën (17,4\%), Volkswagen $(15,1 \%)$, Fiat $(13,7 \%)$ i Renault (13,5\%) oraz dwa ze Stanów Zjednoczonych: GM (16,5\%) i Ford (12,5\%). Udział koncernów japońskich wyniósł odpowiednio: Toyoty (8,3\%), a Hondy (0,1\%) (tab. 2).

W bardzo udanym 2011 r. udział przemysłu samochodowego w tworzeniu argentyńskiego PKB wyniósł 1,2\% oraz aż 6,6\% PKB wytwarzanego przez przemysł. Do tego należy jeszcze dodać 400 zakładów funkcjonujących w tym roku w sektorze części samochodowych, których udział w tworzeniu PKB wyniósł $1,4 \%$ oraz $8,4 \%$ PKB wytwarzanego przez przemysł. Udział przemysłu samochodowego w eksporcie wyniósł 13,4\%, a sektora części samochodowych 3,1\%, natomiast ich udział w wartości eksportu przemysłu wyniósł odpowiednio: 38,8\% i 9,0\% (Anuario ADEFA 2011 2012; Datos de la industria autopartista 2011 2012). 
Podsumowanie

W rozwoju argentyńskiego przemysłu samochodowego, od czasów jego powstania na początku lat 50. XX w. do 2011 r., można wyróżnić trzy główne fazy. Związane są one z jednej strony ze zmianami uwarunkowań wewnętrznych, kształtowanych przez politykę państwa w stosunku do tego sektora oraz reakcją na nią firm krajowych i międzynarodowych koncernów. Nieodłącznym elementem uwarunkowań wewnętrznych, wpływających na rozwój tego sektora, była również sytuacja gospodarcza kraju, która kształtowała wielkość rynku wewnętrznego. $Z$ drugiej zaś strony, na rozwój tego sektora bardzo duży wpływ miały też uwarunkowania zewnętrzne, związane z procesami globalizacji przemysłu motoryzacyjnego oraz jej regionalną integracją w ramach Mercosur.

Pierwsza faza (1952-1975) wiąże się z wprowadzeniem przemysłu samochodowego do Argentyny, co w pierwszym etapie dokonało się przy znacznym zaangażowaniu kapitałów państwowych oraz prywatnych przedsiębiorców argentyńskich, natomiast w drugim etapie - charakteryzującym się konsolidacją działających w kraju zakładów - decydującą rolę odegrały koncerny międzynarodowe. Druga faza (1976-1990) charakteryzuje się głębokim kryzysem sektora motoryzacyjnego, na który złożyły się niekorzystna sytuacja gospodarcza kraju oraz błędnie prowadzona polityka przemysłowa w tym sektorze, zbytnio liberalizująca import gotowych pojazdów. Doprowadziła ona nie tylko do spadku krajowej produkcji, ale także do wyjścia z argentyńskiego rynku kilku dużych koncernów międzynarodowych. Ostatnia trzecia faza (1991-2011) cechuje się ponownym dynamicznym wzrostem produkcji, która w 2011 r. osiągnęła największą w historii wielkość. Sukces ten zawdzięcza Argentyna nie tyko umiejętnie prowadzonej polityce w tym sektorze, w dużej mierze nastawionej na eksport. Wykorzystano w niej fakt postępującej integracji w ramach Mercosur, ale również otwarcia się brazylijskiego rynku samochodowego. Rozwijany od połowy lat 90. XX w. wspólny rynek państw Mercosur wpłynął także na zmianę globalnych strategii koncernów międzynarodowych, które ponownie zainteresowały się rozwijaniem produkcji w tym kraju. Biorąc pod uwagę wartości wskaźników motoryzacji w państwach tego regionu, sektor samochodowy ma przed sobą bardzo dobre perspektywy rozwoju, o ile tylko uda się w nich utrzymać odpowiednio wysokie tempo rozwoju gospodarczego, poprawę warunków życia i wzrost konsumpcji indywidualnej.

Postępująca integracja w ramach Mercosur wydaje się przynosić argentyńskiemu przemysłowi samochodowemu coraz większe korzyści. Wymagało to jednak zrezygnowania z prowadzenia rywalizacyjnej polityki z Brazylią o przyciąganie firm z tego sektora, a postawienie raczej na politykę współpracy i specjalizacji w określonych typach samochodów, których produkcja w Argentynie była bardziej opłacalna. Coraz większe zaawansowanie i „uzależnienie" produkcji od nowych technologii wiąże ten sektor z gospodarką opartą na wiedzy. 


\section{Literatura / References}

Albornoz, F., Yoguel, G. (2004). Competitiveness and production networks: the case of the Argentine automotive sector. Industry and Corporate Change, 13(4), 619-641, doi:10.1093/icc/dth025.

Aliberti, M., Casati, D., Galindo, D., Riveros, M., Vargas, L. (2010). Industria Automotriz Argentina Año 2010. Universidad Nacional de Cuyo, Facultad de Ingenieria Industrias y Servicios II, Mendoza.

Anuario ADEFA 2010 (2011). Asociación de Fabricantes de Automotores - ADEFA. Buenos Aires: http://www.adefa.com.ar/v2/anuario_2010/.

Anuario ADEFA 2011 (2012). Asociación de Fabricantes de Automotores - ADEFA, Buenos Aires: http://www.adefa.com.ar/v2/anuario_2011/.

Barbero, M.I., Motta, J. (2007). Trayectoria de la industria automotriz en la Argentina desde sus inicios hasta fines de la decada de 1990. W: M. Delfini, D. Dubbini, N. Lugones, I.N. Rivero (red.), Innovación y empleo en tramas productivas de Argentina. Universidad Nacional de General Sarmiento, Buenos Aires: Prometeo Libros, 189-229.

Belini, C. (2006). Negocios, poder y politica industrial en los origenes de la industria automotriz argentina, 1943-1958. Revista de Historia Industrial, 31(2), 109-135.

Biggart, N.W., Guillen M.F. (1999). Developing difference: Social organization and the rise of the auto industries of South Korea, Taiwan, Spain and Argentina. American Sociological Review, 64(5), $722-747$.

Catalan, J. (2010). Strategic policy revisited: The origins of mass production in the motor industry of Argentina, Korea and Spain, 1945-87. Business History, 52(2), 207-230.

Catalano, A.M., Novick, M.S. (1998). The Argentine Automotive Industry: Redefining Production Strategies, Markets and Labour Relations. W: J.P. Tuman, J.T. Morris (red.), Transforming the Latin American Automobile Industry: Unions, Workers, and the Politics of Restructuring. Armonk New York: M.E. Sharpe Publisher, 26-76.

Datos de la industria autopartista 2011 (2012). Asociación de Fábricas Argentinas de Componentes ADEFA, Buenos Aires, http://www.afac.org.ar/UserFiles/File/HOME/Datos\%20sectoriales\%20 2011.pdf.

Dorocki, S. (2010). Współczesne procesy internacjonalizacji produkcji i delokalizacji przemysłu samochodowego Francji. Prace Komisji Geografii Przemystu Polskiego Towarzystwa Geograficznego, $16,125-136$.

Foreign Investment in Latin America and the Caribbean 1998 (1999). United Nations Economic Commission for Latin America and the Caribbean (ECLAC), Santiago de Chile.

Garzon, J.M., Berniell, I. (2006). Los ultimos 40 años de la produccion automotriz. ¿Radografia de una industria argentina? Serie Documentos de trabajo, Instituto de Estudios sobre la Realidad Argentina y Latinoamericana (IERAL). Cordoba: Fundación Mediterránea.

Gocłowska-Bolek, J. (2007). Rozwój oparty o strategię substytucji importu w krajach Ameryki Łacińskiej. Ameryka Łacińska, 3-4(57-58), 10-29.

Ianni, V.L. (2008). La especificidad del desarrollo de la industria automotriz en la Argentina, 19591963. Estudos Ibero-Americanos, PUCRS, 34(2), 97-113.

Kilar, W., Cieluch, M. (2008). Kształtowanie się i organizacja przestrzenna korporacji ponadnarodowej Honda. Prace Komisji Geografii Przemystu Polskiego Towarzystwa Geograficznego, 10, 188-203.

Kosacoff, B., Todesca, J., Vispo, A. (1991). La transformación de la industria automotriz Argentyna. Su integración con Brazil. CEPAL, Documento de trabajo n. 40, Buenos Aires. 
Lizak, P. (2012). Kształtowanie się aliansu strategicznego firm Nissan i Renault. Prace Komisji Geografii Przemystu Polskiego Towarzystwa Geograficznego, 20, 108-123.

MacDonald, N. (1988). Henry J. Kaiser and the Establishment of an automobile industry in Argentina. Business History, 30(3), 329-345.

Miozzo, M. (2000). Transnational Corporations, Industrial Policy and the 'War of Incentives': The Case of the Argentine Automobile Industry. Development and Change, 31(3), 651-680.

Schvarzer, J. (1995). La reconversión de la industria automotriz argentina: un balance a mitad de camino. Revista Ciclos en la Historia, la Economía y la Sociedad, 5(8), 5-27.

Wójtowicz, M. (2008). Rozwój przemysłu samochodowego w Brazylii w latach 1957-2005. Prace Komisji Geografii Przemystu Polskiego Towarzystwa Geograficznego, 10, 140-153.

Żuławska, U. (2004). System gospodarczy krajów Ameryki Łacińskiej. Warszawa: Wydział Geografii i Studiów Regionalnych UW.

Mirosław Wójtowicz, dr, Uniwersytet Pedagogiczny w Krakowie, Instytut Geografii, Zakład Geografii Społeczno-Ekonomicznej.

Doktor nauk o Ziemi w zakresie geografii (specjalność geografia społeczno-ekonomiczna), adiunkt w Zakładzie Geografii Społeczno-Ekonomicznej Uniwersytetu Pedagogicznego w Krakowie. Jego zainteresowania badawcze koncentrują się wokół zagadnień procesów urbanizacji oraz industrializacji w Ameryce Łacińskiej, ze szczególnym uwzględnieniem Argentyny, Brazylii i Meksyku.

Mirosław Wójtowicz, Ph.D. in Earth Sciences in the field of Geography (specialization in Socio-Economic Geography), Senior Lecturer in the Department of Socio-Economic Geography at Pedagogical University in Cracow. His research interests focus on issues of urbanization and industrialization process in Latin America, with particular emphasis on Argentina, Brazil and Mexico.

adres/address: Uniwersytet Pedagogiczny w Krakowie

Instytut Geografii, Zakład Geografii Społeczno-Ekonomicznej

ul. Podchorążych 2, 30-084 Kraków, Polska

e-mail: mwojt@up.krakow.pl 